\title{
CAREER PATTERNS IN SELF-EMPLOYMENT AND CAREER SUCCESS
}

\author{
Michael Koch ${ }^{\mathrm{a} *}$, Sarah Park ${ }^{\mathrm{b}}$, Shaker A. Zahra ${ }^{\mathrm{c}}$ \\ ${ }^{\mathrm{a}}$ Kent Business School \\ University of Kent \\ Sibson Building \\ Park Wood Road \\ Canterbury, CT2 7FS, United Kingdom \\ Tel: +44 (0)1227 823797 \\ Email: m.koch@kent.ac.uk \\ ${ }^{\mathrm{b}}$ Kent Business School \\ University of Kent \\ Sibson Building \\ Park Wood Road \\ Canterbury, CT2 7FS, United Kingdom \\ Tel: +44 (0)1227 816592 \\ Email: J.W.Park@kent.ac.uk \\ ${ }^{\mathrm{c}}$ University of Minnesota \\ Carlson School of Management
}

Strategic Management \& Entrepreneurship Department

321-19th Avenue South, Suite 3-430

Minneapolis, MN55455-040, USA

Tel: +1 (612) 6266623

Email: zahra004@umn.edu

* Corresponding author 


\begin{abstract}
A substantial body of research examines entry into and exit from self-employment. However, little is known about the career patterns of the self-employed, their transitions into and from self-employment and the success associated with different patterns of their careers. To address these issues, we examine the career patterns of individuals with self-employment experience and their relationship to objective and subjective career success using data from the German Household Panel (SOEP). Our results show that persistent self-employment careers have higher gross labor income and exhibit higher job and life satisfaction than all other self-employment career patterns.
\end{abstract}

\title{
KEYWORDS
}

Career patterns; career success; self-employment

\section{ACKNOWLEDGEMENTS}

The data used in this publication were made available to us by the German Socio-Economic Panel Study (SOEP) at the German Institute for Economic Research (DIW), Berlin. We are grateful to Field Editor Karl Wennberg and four anonymous reviewers for their helpful comments. 


\section{EXECUTIVE SUMMARY}

Most individuals who engage in self-employment do not remain in this employment state for the entire duration of their careers. Movements between self-employment, paid employment, and other career states such as training or unemployment are a common occurrence in contemporary working lives. Despite this fact, we know comparably little about how self-employment interacts with other employment states in a person's career trajectory. Most existing research has not adopted a careers perspective, and treated decisions to enter or exit self-employment as isolated events. Moreover, our knowledge of career success associated with self-employment careers is also limited. Addressing these concerns would allow us to develop a better understanding of different self-employment career patterns and their relationship to career success.

To address these issues, the present study follows two steps: First, using the representative German SOEP panel data of individuals who accumulated self-employment experience over a 26-year span, we establish which self-employment career patterns can be empirically distinguished. We employ sequence analysis, a technique which is used to detect similar patterns in sequences of events, and cluster analysis to identify distinct patterns of self-employment careers. Our analysis identified four distinct clusters, which differ mostly according to the prevalence of self-employment versus other employment states. These are 1) mixed self-employment career patterns (with no dominant employment state), 2) intermittent self-employment career patterns (with relatively short spells in self-employment and a stronger focus on paid employment), 3) necessity self-employment career patterns (with long spells of unemployment between paid or self-employment), and 4) persistent self-employment career patterns (with mostly self-employment). Second, we develop and test theory on the relationship between different self-employment career patterns and both objective as well as subjective career success. Objective career success refers to career attainments which can be 
evaluated directly and objectively by others and is measured as gross labor income in our study. Subjective career success is measured as job satisfaction and life satisfaction respectively. We hypothesize that objective career success as well as both types of subjective career success are higher in persistent self-employment career patterns. Our results support these hypotheses.

Our study makes several contributions. First, it demonstrates that self-employment careers can result in a variety of patterns, which can be classified into four distinct clusters. Our analysis provides a clearer understanding of how self-employment is embedded in individuals' career trajectories, which often include an important number of transitions between different employment states. Second, our study also provides a nuanced picture of the career success associated with different self-employment career patterns. The result that persistent self-employment careers are related to higher levels of objective and subjective career success implies that individuals need to persevere in self-employment in order to reap its benefits. Hence, policymakers should not only focus on enabling people to become selfemployed in the first place, but also on helping them to persist in this employment state. 


\section{INTRODUCTION}

Transitions between different employment states are common in any person's career. Most individuals who establish new ventures transition into self-employment from paid employment (Sørensen \& Fassiotto, 2011). Moreover, many individuals also move back into paid employment at some point in their careers, for a variety of reasons such as company failure, harvest or founder succession (Timmons, 1990; Wennberg \& DeTienne, 2014). Existing research has identified numerous factors which influence intentions or actual decisions to enter (e.g., Shane, Locke \& Collins, 2003) or exit self-employment (e.g., Wennberg \& DeTienne, 2014), including in particular attitudes and motivations of the selfemployed (e.g., Kolvereid, 1996; Delmar \& Davidsson, 2000; Carter, Gartner, Shaver, \& Gatewood, 2003; Souitaris, Zerbinati \& Al-Laham, 2007). Research has also sought to capture the heterogeneity of self-employed individuals by examining different categories of

self-employment. Important distinctions between categories of self-employed individuals are based on their inferred motivations (e.g., opportunity and necessity self-employment; Block \& Sandner, 2009), engagement in one or several ventures (e.g., serial vs. novice or portfolio entrepreneurs; Westhead, Ucbasaran \& Wright, 2005), or number of employees (e.g., solo self-employed and employers; Van Stel \& de Vries, 2015).

Even though there is a significant body of research on the characteristics of selfemployed individuals, our knowledge of self-employment careers is comparatively limited (Burton, Sørensen \& Dobrev, 2016). Past studies have treated entries into or exits from selfemployment as isolated events, paying less attention to transitions into and out of selfemployment in the broader context of career trajectories that unfold over time. However, careers often transcend boundaries between multiple occupations and staying in one particular career state is increasingly less common (Arthur \& Rousseau, 2001). Consequently, the self-employed are likely to follow a variety of distinct career patterns. The paucity of 
research that adopts a longitudinal career perspective means that we know little about selfemployment career patterns. Furthermore, the association between career patterns and career success in entrepreneurship or self-employment is yet to be examined. For instance, although it is assumed that persistence in self-employment is vital for reaping its monetary benefits (e.g., Patel \& Thatcher, 2014), we do not know how different self-employment career patterns are associated with career success.

Prior research on career success of entrepreneurs and self-employed has also examined objective (e.g., Carter, 2011; Hamilton, 2000; Campbell, 2013; Luzzi \& Sasson, 2016) and subjective career success (e.g., Stephan, 2018), but these studies do not adopt a career perspective. In addition, researchers have studied career success by comparing categories of self-employment such as necessity and opportunity self-employment to paid employment (e.g., Binder \& Coad, 2016), but not across different self-employment career patterns. These factors suggest that a better understanding of self-employment career patterns and their relationship with career success would help to enrich the literature on entrepreneurial careers, and inform policy as well as the career choices of potential entrepreneurs and self-employed individuals. This article addresses these issues.

In this article, we examine the relationship between different self-employment career patterns and objective and subjective career success. A career pattern refers to the "number, duration, and sequence of jobs in the work history of individuals" (Savickas, 2001: 54). Objective career success denotes career attainments which can be evaluated directly and objectively by others using salary as a key indicator, whereas subjective career success indicates an individual's satisfaction with her/his job and life (Heslin, 2005). We investigate how distinct clusters of persistent, intermittent, and mixed self-employment career patterns relate to gross labor income, job satisfaction and life satisfaction. While persistent selfemployment career patterns are characterized by few transitions between self-employment 
and other employment states and comparably long or frequent spells in self-employment, intermittent self-employment career patterns are mostly shaped by paid employment and only a few or short spells in self-employment. Mixed self-employment career patterns have no clear focus on a particular employment state and exhibit frequent changes between different employment states. Even though we focus on these three career patterns, our empirical analyses also reveal a fourth career pattern, necessity self-employment, which is shaped by significant spells of unemployment interspersed with spells in mostly paid employment or self-employment. We find that persistent self-employment career patterns are associated with higher gross labor income than all other self-employment career patterns. Further, persistent self-employment career patterns exhibit higher job and life satisfaction than all other career patterns.

Our study contributes to the literature on entrepreneurial careers in a number of ways. First, by examining the career patterns of self-employed individuals over time, the results allow us to appreciate these careers as a whole, as opposed to isolated events in the careers of individuals. This perspective enables us to observe "meaningful fluctuations" (Abbott, 1990) in self-employment careers. Thus, our study addresses a shortcoming of existing research where there is little focus on persistence in entrepreneurship over time (Patel \& Thatcher, 2014), and a lack of empirical longitudinal research examining relevant career paths. Most existing empirical studies treat self-employment as an end-state in which individuals are selfemployed for the duration of their careers, failing to consider the possibility of a return to paid employment at some future point in time (Marshall, 2016; Burton, Sørensen \& Dobrev, 2016). There is some research on individuals moving between self-employment and paid employment, examining for instances their subsequent incomes (e.g., Luzzi \& Sasson, 2016; Hyytinen \& Rouvinen, 2008), job stability (Failla, Melillo \& Reichstein, 2017) or likelihood to re-enter self-employment (Hsu, Shinnar, Powell \& Coffey, 2017). However, this research 
stream generally does not study the multiple transitions that might occur between selfemployment and other employment states over a prolonged period. It also overlooks how they relate to different types of career success. As a result, our study contributes to "research investigating the sequences of career decisions (including decisions to pursue an entrepreneurial career) over an extended period" (Shepherd, Williams \& Patzelt, 2015: 21).

Applying a longitudinal approach that considers a 26-year span, our study also contributes to ongoing discussions on entrepreneurial careers from a life-course perspective (e.g., Jayawarna, Rouse \& Kitching, 2013; Obschonka, Silbereisen \& Schmitt-Rodermund, 2010). This perspective holds that human development is a life-long process and that lives need to be studied over extended periods of time (Elder, Johnson \& Crosnoe, 2003). Currently, there is a paucity of empirical research that adopts a life-course perspective on entrepreneurial careers and life-course considerations are mostly neglected in entrepreneurship research (Obschonka, Silbereisen, Schmitt-Rodermund, \& Stuetzer, 2011). Moreover, by showing the extent to which self-employed move between different employment states, our results inform the debate on the prevalence of boundaryless careers (e.g., Dries, Van Acker \& Verbruggen, 2012).

Second, by demonstrating different levels of objective and subjective career success across distinct types of self-employment career patterns, our study adds to the literature on career success of entrepreneurs. To date, research on the success outcomes of entrepreneurial activity has mostly focused on companies instead of individuals (Lau, Shaffer \& Au, 2007). Moreover, while there is some research on individual career success of entrepreneurs (e.g., Benz \& Frey, 2008a; Hamilton, 2000), there is limited knowledge of the objective and subjective career success which is associated with different career patterns. Self-employment is not a discrete state. Rather, it is a part of an individual's career that unfolds over time. This 
suggests that, to understand career success of the self-employed, we need to investigate career success in the context of career trajectories.

Having presented our study's focus and research question, the next section of the article presents our theory and hypotheses on different types of self-employment career patterns and objective and subjective career success. The subsequent section presents the study's sample and data, methods, and results. The final section of the article presents a discussion of our key findings and their implications for theory, policy and practice.

\section{CAREERS IN SELF-EMPLOYMENT AND CAREER SUCCESS}

Self-employment career patterns can differ significantly, depending on the frequency of transitions between different employment states such as self-employment and paid employment, and the relative proportion of different states in a career. Prior research indicates that the length of time an individual works in self-employment differs (Rocha, Carneiro, \& Varum, 2015). Given these variations, we examine three types of career patterns which differ in their frequency of transitions between different employment states; these states denote an individual's occupational status at a given point in time, and the relative proportion of self-employment states. The three patterns are: persistent self-employment careers, intermittent self-employment careers, and mixed self-employment careers.

\section{Self-employment career patterns and objective career success}

Career success refers to the outcome of a person's career experiences (Arthur, Kapova \& Wilderom, 2005). Objective career success refers to career attainments, which can be evaluated directly and objectively by others including for instance salary or the number of promotions (Ng, Eby, Sorensen \& Feldman, 2005). Previous research on objective career success has found significant income differences between individuals in paid employment and self-employment. There is substantial evidence that self-employed individuals generally earn lower median incomes than individuals in paid employment (e.g., Evans \& Leighton, 
1989; Hamilton, 2000, Sorgner, Fritsch \& Kritikos, 2017; Åstebro, 2012). This is often because new ventures operate with limited financial resources. They frequently underperform and may eventually fail (e.g., Phillips \& Kirchhoff, 1989), which implies that new ventures tend to generate comparably lower incomes for their owners.

Still, several studies provided evidence for higher incomes for the self-employed compared to individuals in paid employment. For instance, using data from the National Longitudinal Survey of Youth (NLSY), Hartog, van Praag and van der Sluis (2010) found that the self-employed achieve higher earnings than employees, although this earnings differential is only valid for the upper echelon of the general ability distribution, indicating that self-employment only pays off for high-ability individuals. Luzzi and Sasson (2016), Campbell (2013), as well as Daly (2015) found that in some contexts, individuals with entrepreneurial experience earn higher incomes in subsequent paid employment compared to matched individuals without entrepreneurial experience. Based on an examination of data from the NLSY, Manso (2016) found that the self-employed have on average ten percent higher life-time earnings than salaried employees with similar characteristics. Importantly, this finding applies only to those self-employed individuals who do not return to paid employment within the first few years of self-employment.

The results of Manso's study suggest that a career shaped by persistent selfemployment can be a means for realizing incomes that are higher than in intermittent selfemployment. Theories of learning and matching in self-employment support this notion. According to these theories (e.g., Åstebro, 2012; Åstebro \& Chen, 2014), people who engage in self-employment initially have no knowledge about their ability to be successful in this career state. Those who fail, or realize that their skills are not well-matched to selfemployment, return to paid employment quickly. Conversely, other individuals demonstrate their ability to be successful in self-employment, and are more likely to persist in this career 
state. Over time, people who persist in self-employment should accumulate relevant knowledge, social networks and other resources that help them to realize incomes that are higher than in comparable paid employment. Prior research found that self-employed individuals acquire personal knowledge and skills, which then help them to perform better over time (e.g., Minniti \& Bygrave, 2001; Cope, 2005; Gompers, Kovner, Lerner \& Scharfstein, 2010). Consequently, persistent self-employment careers should be associated with higher objective career success than intermittent self-employment careers; i.e., those careers that are predominantly shaped by paid employment and have more limited spells in self-employment.

Furthermore, persistent self-employment careers that exhibit few transitions between self-employment and other employment states should be related to higher objective career success than mixed self-employment careers, which are likely marked by volatility and lack of commitment to a particular employment state. For individuals pursuing such careers, "persistence in self-employment is critical for fulfilling personal goals and realizing economic benefits" (Patel \& Thatcher, 2014: 1935). In particular, human capital is critical for venture success (Åstebro \& Yong, 2016) and acquiring the skills needed to run a business successfully takes time.

Mixed self-employment careers with frequent transitions into different states are often associated with low-wage, peripheral work and poor working conditions, which should be associated with lower objective career success (Kovalenko \& Mortelmans, 2014). Frequent changes are likely to prevent people from building the firm-specific human capital and networks that are crucial for achieving objective career success (Judge, Klinger \& Simon, 2010; Seibert, Kraimer \& Liden, 2001). Given these realities, some research shows that individuals with unstable employment patterns have lower incomes (Åstebro \& Thompson, 2011). These observations suggest the following hypotheses: 
Hypothesis 1A: Objective career success will be higher in persistent self-employment career patterns than in intermittent self-employment career patterns.

Hypothesis 1B: Objective career success will be higher in persistent self-employment career patterns than in mixed self-employment career patterns.

\section{Self-employment career patterns and subjective career success}

Subjective career success refers to "the individual's internal apprehension and evaluation of his or her career" (Arthur, Khapova, \& Wilderom, 2005: 179). Such success is not objectively verifiable by a third party; rather, it can only be experienced by the individual engaged in a career (Heslin, 2005). Satisfaction with lives and jobs are two of the most frequently used measures of the subjective career success of the self-employed (e.g., Benz \& Frey, 2008a; Blanchflower \& Oswald, 1998; Feldman \& Bolino, 2000). Life satisfaction is “a global cognitive evaluation or judgment of one's satisfaction with his or her life" (Heller, Watson, \& Ilies, 2004: 574). Meanwhile, job satisfaction refers to "a positive (or negative) evaluative judgment one makes about one's job or job situation" (Weiss, 2002: 175).

Job satisfaction. Previous research indicates that self-employment is related to greater job satisfaction (Blanchflower \& Oswald, 1998; Benz \& Frey, 2008a; Fuchs-Schündeln, 2009; Hundley, 2001; Schneck, 2014). In particular, the autonomy derived from being selfemployed is a major contributor to job satisfaction, which may explain why people persist in self-employment despite unsatisfactory economic returns (Benz \& Frey, 2008a; Feldman \& Bolino, 2000; Hamilton, 2000; Kolvereid, 1996; Hytti, Kautonen \& Akola, 2013). Compared to individuals in paid employment, the self-employed are generally able to determine (and even control) more aspects of their work and are therefore likely to enjoy higher levels of autonomy in their work (Carter, 2011; van Gelderen \& Jansen, 2006; Lange, 2012; VandenHeuvel \& Wooden, 1997). For instance, procedural utility theory posits that individuals not only care about instrumental (monetary) outcomes, but also about how these 
outcomes are generated. Specifically, people value their well-being and the satisfaction of their needs for autonomy, relatedness, and competence (Frey, Benz \& Stutzer, 2004). Following this logic, some individuals value being self-employed "because it gives them a higher measure of self-determination and freedom. In contrast, persons in dependent employment have to obey orders given by their superiors" (Benz \& Frey, 2008b: 362). More autonomy in self-employment is accompanied usually by more flexibility in terms of work schedule, which also contributes to increased job satisfaction (Hundley, 2001). Another nonmonetary benefit from self-employment is doing more interesting work (Benz \& Frey, 2008a). Moreover, self-employed individuals are more likely to use their skills more fully and experience greater task variety as they are more likely to be involved in different aspects of the business as well as managing the business (Hundley, 2001).

Recently, a number of studies have sought to clarify the relationship between selfemployment and job satisfaction by distinguishing between different forms of selfemployment as well as of job satisfaction (e.g., Binder \& Coad, 2016; Sevä, Larsson \& Strandh, 2016; Lange, 2012; Millán, Hessels, Thurik \& Aguado, 2013). The results of these studies show that the positive relationship between self-employment and job satisfaction is weakened or non-existent under certain conditions (Binder \& Coad, 2016; VandenHeuvel \& Wooden, 1997). One important boundary condition can be found in the distinction between self-employment out of necessity vs. opportunity-based self-employment. Using a matching approach and based on data from the German SOEP panel, Binder and Coad (2016) examined how self-employment is related to satisfaction with different domains of life. They found that individuals in self-employment are generally more satisfied with their job than a control group of employed counterparts. However, when distinguishing between cases of opportunity self-employment (measured as transition from paid employment to selfemployment) and necessity self-employment (measured as transition from unemployment to 
self-employment), their analysis showed that benefits in terms of job satisfaction only exist for individuals in opportunity self-employment. Other studies found that individuals in necessity self-employment report lower intrinsic work motivation, lower autonomy and consequently lower job satisfaction than their counterparts in opportunity self-employment (Sevä, Larsson, \& Strandh, 2016). A more fine-grained analysis of job satisfaction also shows that the self-employed are not necessarily satisfied with all aspects of their jobs. For instance, Millán, Hessels, Thurik and Aguado (2013) examined job satisfaction of self-employed and paid employees in a European sample, distinguishing between satisfaction with type of work and satisfaction with job security. Their results indicate that, compared to paid-employed individuals, self-employed are on average more satisfied with type of work and less satisfied with job security.

A career pattern of persistent self-employment, which is not significantly interspersed with unemployment but characterized by continuous spells in self-employment, is more likely to be driven by opportunities instead of necessity. In such a career, autonomy and independence should be higher than in a career of intermittent self-employment; i.e., a career that is shaped mostly by paid employment, and where control over work is therefore more often limited. Individuals in persistent self-employment careers should therefore experience higher levels of job satisfaction compared to those individuals with career patterns that are more significantly shaped by other employment states, including mixed and intermittent selfemployment careers. In addition, mixed self-employment career patterns, with their lack of focus on a particular employment state, could also reflect low occupational and organizational commitment, both of which are strongly negatively related to subjective career success (Ng \& Feldman, 2014). Significant transitions between different employment states also prevent individuals from building relevant social capital (Feldman \& $\mathrm{Ng}, 2007$; $\mathrm{Ng} \&$ Feldman, 2014), which in turn is negatively related to job satisfaction (Flap \& Völker, 2001). 
Furthermore, transitions between different employment states that characterize mixed selfemployment career patterns may indicate that an individual is undecided or not comfortable with his or her career. Career indecision and lack of comfort with career choices are negatively related to job satisfaction (Earl \& Bright, 2007). Together, these observations suggest the following hypotheses:

Hypothesis 2A: Job satisfaction will be higher in persistent self-employment career patterns than in mixed self-employment career patterns.

Hypothesis 2B: Job satisfaction will be higher in persistent self-employment career patterns than in intermittent self-employment career patterns.

Life satisfaction. As we noted earlier, research suggests that self-employment is related to higher levels of autonomy and job control when compared to paid employment. The self-determination theory (Ryan \& Deci, 2000) advances that the fulfillment of autonomy needs leads to better personal well-being that translates into higher satisfaction with life (Blanchflower \& Oswald, 1998). A substantial part of this relationship is accounted for by the positive relationship between autonomy and job satisfaction, a key component of life satisfaction (Schjoedt \& Shaver, 2007). Thus, some researchers have also noted that selfemployment benefits the experience of "flow", which is characterized by immersion, absorption, work enjoyment and intrinsic work motivation (Salanova, Bakker \& Llorens, 2006), more than paid employment (Hessels, Arampatzi, van der Zwan \& Burger, 2018). This is likely to be the case because self-employment offers more opportunities for meaningful and challenging work, resulting in higher motivation and improved life satisfaction (Erdogan, Bauer, Truxillo \& Mansfield, 2012). Empirical research using large-scale surveys has found a generally positive relationship between being self-employed and life satisfaction (Andersson, 2008; Blanchflower, 2004; Blanchflower \& Oswald, 1998; Sevä, Vinberg, Nordenmark \& Strandh, 2016; Stephan \& Roesler, 2010). More recent research has explored the specific 
psychological mechanisms through which self-employment enhances life satisfaction in more detail, investigating for instance the intermediary role of needs satisfaction or psychological functioning. An exemplary study by Nikolaev, Boudreaux and Wood (in press) found that self-employed individuals experience higher levels of life satisfaction than those in paid employment, and this relationship was mediated by personal functioning (e.g., perceptions of meaning and purpose, autonomy and control) and social functioning (e.g., sense of belonging, local support). In a similar study, Shir, Nikolaev and Wincent (2019) found evidence that self-employment is related to higher levels of well-being (including life satisfaction), mediated by the satisfaction of three basic psychological needs autonomy, relatedness, and competence.

The robust evidence we have just cited indicating a positive link between selfemployment and life satisfaction notwithstanding, analysis of different self-employment contexts reveals some exceptions. For instance, studies using German and British panel data have found that people in opportunity self-employment benefit from higher life satisfaction compared to those in paid employment, while people in necessity self-employment do not (Binder \& Coad, 2013, 2016). A related study complements these results by showing that the transition from paid employment to self-employment is negatively related to life satisfaction for those self-employed individuals who earn low incomes from self-employment (Binder, 2017). The threat of job loss also seems to affect life satisfaction of the self-employed. Research by Hetschko (2016) shows that losing as well as the mere prospect of losing selfemployment are both related to more important reductions in life satisfaction than (the prospect of) losing paid employment.

Persistent self-employment careers indicate strong commitment to self-employment. This commitment translates into entrepreneurial success, which in turn contributes to life satisfaction (Przepiorka, 2017). A persistent career in self-employment also affords 
individuals the chance to establish and grow their business. Research suggests that life satisfaction is higher for self-employed running an established business rather than being in an early stage of self-employment (Zbierowski, 2014). The situation is likely to be different with the frequent transitions found in mixed self-employment career patterns. These transitions might also indicate persistent career indecisions. They may also signal difficulties that could prevent an individual from making a career decision (Gati, Asulin-Peretz \& Fisher, 2012), and which in turn is negatively related to life satisfaction (Jaensch, Hirschi \& Freund, 2015). Thus, career patterns that are marked by persistent self-employment should be associated with higher life satisfaction levels than career patterns reflective of intermittent or mixed self-employment. These observations lead to the following hypotheses:

Hypothesis 3A: Life satisfaction will be higher in persistent self-employment career patterns than in mixed self-employment career patterns.

Hypothesis 3B: Life satisfaction will be higher in persistent self-employment career patterns than in intermittent self-employment career patterns.

\section{METHODOLOGY}

\section{Data}

To test our hypotheses, we draw on data from the German Socio-Economic Panel (SOEP) to examine transitions into and from self-employment. The SOEP is a long-running panel study of several thousand households representative for Germany, collecting detailed socio-demographic information on an annual basis (Wagner, Frick \& Schupp, 2007). SOEP data have been widely used to examine career choices of individuals (e.g., Biemann, Zacher \& Feldman, 2012; Kattenbach et al., 2014), especially the career choices of self-employed (e.g., Caliendo, Fossen \& Kritikos, 2014; Fritsch \& Rusakova, 2010). Given our research focus, we included all individuals in the panel who have 1) acquired self-employment experience at some point of their working lives, and 2) submitted data to the panel every year 
between 1991 and the year 2016. 1991 was the first year after the German reunification in 1990, and therefore the first year in which SOEP contained data of respondents from the reunified Germany. Farmers are frequently excluded in the analysis of objective and subjective career success of the self-employed (e.g., Hamilton, 2000; Binder \& Coad, 2016). Considering that farmers in Germany derive a significant part of their income from subsidies, we excluded individuals whose only career spells in self-employment consisted of farming. Since they do not operate their own business, we also excluded helpers in a family business (Caliendo, Fossen \& Kritikos, 2014). This approach resulted in a sample of 205 unique individuals, with a career length of 26 years each. This length is consistent with best practice recommendations regarding sequence length in career research (Dlouhy \& Biemann, 2015). The equal length of all examined sequences facilitates comparisons between sequences. Further, the length of careers studied allows for the detection of meaningful and interpretable patterns that span a significant part of an adult's working life.

\section{Dependent variables}

Objective career success is measured using the natural log of gross labor income adjusted for inflation with 2016 as the base year (Manso, 2016). SOEP respondents were asked to provide an estimate of their monthly labor income before taxes and social security contributions, excluding special payments or benefits.

Subjective career success is operationalized using life satisfaction and job satisfaction. Life satisfaction was captured with a single item based on the question "How satisfied are you with your life, all things considered?" (measured using a scale from $0=$ completely dissatisfied to $10=$ completely satisfied). Similarly, job satisfaction was assessed with the question "How satisfied are you with your job?" with answers ranging from $0=$ completely dissatisfied to $10=$ completely satisfied.

The use of single-item measures can be justified and appropriate when a construct is 
sufficiently narrow, unidimensional rather than multidimensional, and clear to respondents (Wanous \& Hudy, 2001). Previous research has established that both job and life satisfaction can reasonably be measured with a single question (Fisher, Matthews \& Gibbons, 2016; Wanous, Reichers \& Hudy, 1997). For instance, in the case of job satisfaction, in a metaanalysis of studies using single- as well as multi-item measures of job satisfaction, Wanous, Reichers and Houdy (1997) found evidence of strong correlations between both types of measures, indicating convergent validity. A single-item measure for job satisfaction has been used in a variety of studies, including but not limited to SOEP data (e.g., Riza, Ganzach \& Liuz, 2018; Kampkötter, 2017; Coad \& Binder, 2014). The single-item measure of life satisfaction based on SOEP has also been employed in numerous studies (e.g., Wortman \& Lucas, 2016; Hülür et al., 2017; Rohrer et al., 2018), and is regarded as reliable (Schilling, 2005; Boyce, Wood \& Ferguson, 2016). Using a Stable Trait, Autoregressive Trait, State (STARTS) Model, an investigation of the reliability of the single-item measure of life satisfaction used in SOEP also demonstrated that this measure passed the heuristic for minimally acceptable reliability of 0.70 (Lucas \& Donnellan, 2012). We also considered other measures of life satisfaction that are part of SOEP. Specifically, SOEP also includes measures of life satisfaction that deal with satisfaction regarding different domains of life such as satisfaction with health, leisure time or dwelling. However, existing research on life satisfaction has found that an assessment of life satisfaction based on satisfaction with different life domains is generally unsatisfactory. People place varying degrees of emphasis on different life domains and employ unique criteria for judging success in those domains; a global evaluation of life satisfaction is therefore preferable (Pavot \& Diener, 1993). In terms of the timing of data collection, SOEP data are collected every year starting from February, with $80 \%$ of the data collection completed within three months (Gerstorf \& Schupp, 2016). 


\section{Independent variable}

Our independent variable for the regression analyses is a categorical variable that consists of four self-employment career patterns: Mixed, intermittent, necessity and persistent self-employment. To derive these patterns, we used a two-step approach. The first step involved sequence analysis. A sequence is an "ordered listing of events" (Biemann \& Datta, 2014: 51). Sequence analysis is a technique that was originally used to analyze sequences in the natural sciences, but has since then spread to fields such as psychology, linguistics or sociology (Abbott, 1995). It has been particularly fruitful for the analysis of life and career trajectories (e.g. Blair-Loy, 1999, Joseph et al., 2012). It is particularly suitable for “measuring entire careers 'as they are'” (Vinkenburg \& Weber, 2012: 601-602). A key advantage of sequence analysis is "the holistic view that it provides by dealing with whole trajectories" (Studer \& Ritschard, 2016: 481). The objective of sequence analysis is to identify similarities between sequences, which can then be input to clustering methods to establish categories of similar sequence patterns.

For each individual in our sample, we constructed a sequence dataset that contained a single indicator of their respective employment state. This indicator can take five different states, as follows: 1 = self-employment, 2 = paid employment, 3 = vocational training, $4=$ unemployment and $5=$ other (a state which groups together retirement, military/community service, farming and unspecified answers). This indicator allows us to capture differences between all salient employment states. Time units are measured in years.

We conducted sequence analysis using $\mathrm{R}$ and the TraMineR package (Gabadinho et al., 2011). To identify similar sequence patterns, sequence analysis requires the specification of a measure of dissimilarity between sequences. We first compared sequences in terms of 
similarity/dissimilarity using OMspell analysis (Studer \& Ritschard, 2016) ${ }^{1}$. OMspell stands for optimal matching of spells and is a variant of optimal matching. Optimal matching assesses "the resemblance between two sequences of elements by analyzing the 'costs' of transforming one sequence into another" (Biemann \& Wolf, 2009: 980). Specifically, this analysis is based on the assumption that the similarity between any two sequences can be quantified by the number of operations necessary to transform one sequence into another. It requires the definition of substitution costs; i.e., a weighting of the insertion and deletion (indel) operations which are used to make any two sequences more similar to one another. Prior work shows that OMspell with higher expansion cost e (the cost of spell length transformation) is a suitable dissimilarity measure if the focus is on spell duration (Studer \& Ritschard, 2016). In our analysis, we used OMspell with the substitution-cost matrix "INDELS", and expansion cost $0.5^{3}$. Once distances were calculated and a dissimilarity matrix was obtained, a cluster analysis with Wards linkage was employed in a second step to group sequences into a discrete number of meaningful clusters (Pentland, 2003). The cluster analysis allowed us to identify and bundle sequences with respect to the dominance of career experience in self-employment and other employment states.

Based on an assessment of face validity, cluster dendograms, several cluster stop indices (Charrad, Ghazzali, Boiteau \& Niknafs, 2014), a four-cluster solution emerged as the most appropriate characterization of the data. Figure 1 displays sequence index plots, graphically showing the complete sequences for all individuals in their respective clusters.

\footnotetext{
${ }^{1}$ We also examined classic OM and LCS as Studer and Ritschard (2016) suggest that these are also suitable when the focus is on duration and the results of sequence and cluster analyses were qualitatively similar. ${ }^{2}$ For INDELS, R uses Indel_ $i=1 / f_{-} i$ and sets substitution costs as $S c(i, j)=i n d e l \_i+i n d e l_{-} j$ (Gabadinho et al., 2011)

${ }^{3}$ We also conducted further analysis using OMspell with the expansion cost 1 . In addition, we conducted additional analysis using OMspell with "INDELSLOG" which is the only other substitution-cost matrix that can be used with OMspell. The results were qualitatively similar.
} 
Insert Figure 1 about here

Cluster 1 -Mixed self-employment career patterns. This is the biggest of all four clusters uncovered in the study (33\% of the sample). It is characterized by the relatively high number of spells in different states per individual. Thus, there is no dominant employment state in this sequence.

Cluster 2 - Intermittent self-employment career patterns. This cluster (24\% of the sample) includes individuals with only limited self-employment experience (as evidenced by shorter spells in self-employment), but with a strong focus on paid employment.

Cluster 3 -Necessity self-employment career patterns. This cluster (29\% of the sample) mostly includes individuals whose careers are characterized by long spells of unemployment which are interrupted by comparably shorter spells in mostly paid employment or self-employment, pointing at necessity self-employment.

Cluster 4 - Persistent self-employment career patterns. This cluster (14\% of the sample) includes individuals whose careers are mainly shaped by self-employment. Shifts towards self-employment are comparably early and there are few to no transitions back to paid employment.

To summarize, in addition to our theorized career patterns that included mixed, intermittent and persistent self-employment career patterns, a fourth cluster of necessity selfemployment career patterns emerged from the analysis. We included this self-employment career pattern in the analysis. Thus, the four-cluster solution was used as our independent variable in our regression analyses.

\section{Control variables}

Our analyses control for several variables that could influence objective and subjective career success, using the SOEP database. These variables are: gender, age, marital 
status, educational attainment, part-time work experience, full-time work experience $(\mathrm{Ng}$, Eby, Sorensen \& Feldman, 2005), number of children, employment level, job change, satisfaction with health and region.

Gender is a binary variable coded as 1 for female and 0 for male. Age is measured in years. Marital status is a binary variable coded as 1 for married or in partnership and 0 for not married. Educational attainment is measured as the number of years of formal education, including years of schooling and years of tertiary education. Full-time work experience is measured by the number of years in full-time employment. Part-time work experience is measured as number of years in part-time employment. Number of children is the number of dependent children in the household. Employment level is measured with the categories fulltime, part-time and not working. Job change is measured with categories not applicable, job change since last year and no job change since last year. Satisfaction with health is measured

with a single item based on the question "How satisfied are you with your health?" (measured on a scale from $0=$ completely dissatisfied to $10=$ completely satisfied). Region is measured with a dummy variable, coded as 0 for East Germany and 1 for West Germany.

\section{RESULTS}

Tables 1 displays the descriptive statistics and correlation coefficients for all study variables. Inter-variable correlations are generally low. The variance inflation factors were also lower than the standard benchmark of 10 (Hair, Anderson, Tatham, \& Black, 1998), indicating that multicollinearity was not a concern in our study. On average, individuals were 44 years old and had 0.8 children. The age distribution for the first year of our study period 1991 is as follows: 14 individuals of up to 19 years, 77 individuals between 20 and 29 years, 80 individuals between 30 and 39 years, 32 individuals between 40 and 49 years, and 2 individuals older than 50 years. Individuals had on average 13.6 years of education and 16 years of full time work experience. 
Table 2 presents descriptive statistics on gross labor income, job satisfaction and life satisfaction for the four clusters of self-employment career patterns. Figures 2 to 4 provide a graphical representation of the means of each dependent variable in all four self-employment career patterns, including the respective confidence intervals at $95 \%$ level. For objective career success, persistent self-employment patterns had the highest average monthly gross labor income of 4571 Euros, whereas necessity self-employment patterns had the lowest average monthly gross labor income of 2341 Euros. In terms of job satisfaction, persistent self-employment patterns had the highest average job satisfaction of 7.41 , whereas necessity had the lowest average job satisfaction of 6.78. Persistent self-employment patterns also had the highest average life satisfaction of 7.19 and necessity self-employment patterns had the lowest average life satisfaction of 6.82 .

Insert Tables 1 and 2, and Figures 2, 3, and 4 about here

Next, we tested our hypotheses using feasible generalized least square (FGLS) regression analysis. FGLS uses an estimate of the covariance matrix of the errors and does not assume that it is known (Beck \& Katz, 1995). Thus, it produces unbiased estimators and its estimates are more efficient (Kakwani, 1967). FGLS regression is also appropriate for addressing problems of heteroscedasticity and autocorrelation within panels (AR1) (Greene, 2000). Both heteroscedasticity and autocorrelation were present in our data. FGLS regression has been also used by Shi and Prescott (2011) in their study examining the sequence patterns of acquisitions and alliances for similar reasons.

Models 1 and 2 in Table 3 report the results of FGLS regression analyses of gross labor income, our indicator of objective career success. Model 1 only includes control variables and Model 2 adds the self-employment career patterns categorical variable. 
Hypothesis 1A predicted that objective career success will be higher in persistent selfemployment career patterns than in intermittent self-employment career patterns. With the base level intermittent self-employment career patterns, the coefficient for persistent selfemployment career patterns is positive and significant. Thus, Hypothesis $1 \mathrm{~A}$ is supported. In terms of economic significance, gross labor income is $18.9 \%$ higher for persistent selfemployment patterns than for the intermittent self-employment career patterns.

Hypothesis 1B predicted that objective career success will be higher in persistent selfemployment career patterns than in mixed self-employment career patterns. The coefficient for persistent self-employment career patterns is positive and significant when the base level is mixed self-employment career patterns. Thus, Hypothesis $1 \mathrm{~B}$ is supported. The results show that persistent self-employment career patterns have significantly higher gross labor income than mixed self-employment career patterns. In terms of economic significance, gross labor income is $12.6 \%$ higher for persistent self-employment patterns than for the mixed selfemployment career patterns.

We ran additional analyses with a different base level self-employment career pattern to compare all possible career patterns with one another. Overall, the results indicate that persistent self-employment career patterns have the highest gross labor income compared to all other self-employment career patterns. The results appear in Table 3.

Insert Table 3 about here

Models 1 and 2 in Table 4 show the results of the FGLS regression analyses for the dependent variable job satisfaction. Model 1 includes the study's control variables and Model 2 adds the self-employment career patterns categorical variable.

Hypothesis 2A predicted that job satisfaction will be higher in persistent selfemployment career patterns than in mixed self-employment career patterns. Compared to the 
Hypothesis 3B predicted that life satisfaction will be higher in persistent selfemployment career patterns than in intermittent self-employment career patterns. Compared to the base level intermittent self-employment career patterns, the coefficient for persistent self-employment career patterns is positive and significant, supporting Hypothesis 3B. Life satisfaction for persistent self-employment career patterns is 0.245 higher on a $0-10$ scale (or 0.15 standard deviations) than for the intermittent self-employment career patterns.

We ran additional analyses with a different base level self-employment career pattern to compare all possible career patterns with one another. Overall, the results suggest that persistent self-employment career patterns have the highest life satisfaction among the four career patterns.

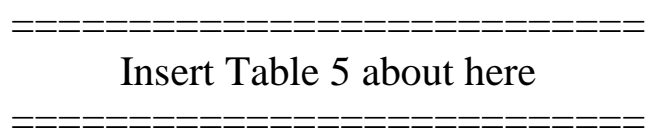

\section{Robustness checks}

To establish the robustness of the results just reported, we conducted additional analyses by excluding the variables full-time work experience and part-time work experience as control variables, as they may be influenced by different career patterns. The results were qualitatively similar. Further, we checked whether our regression results were robust if we include our variable gross labor income as a control variable when we investigated subjective career success. Some prior studies that examine subjective career success included income as a control variable as income has been shown to influence subjective career success. We found that the results of the regression analyses for both job satisfaction and life satisfaction with the inclusion of the variable gross labor income were qualitatively similar. Lastly, we conducted additional tests by only including the independent variables while excluding the control variables. We found that the results of the regression analysis for gross labor income were qualitatively similar. For job satisfaction, while persistent self-employment patterns 
have significantly higher job satisfaction than intermittent and necessity self-employment patterns, there was no significant difference between persistent and mixed self-employment patterns. For life satisfaction, the prob > chi2 statistic for the overall model was not significant. ${ }^{4}$ Overall, these tests provide stronger support for the relationship between the self-employment career patterns and objective career success.

\section{DISCUSSION AND CONCLUSION}

Research suggests that self-employment as a career is not an end-state (Marshall, 2016), as people go back and forth between different jobs including self-employment. Adopting a longitudinal careers perspective, our empirical study identifies four distinct selfemployment patterns that differ significantly in their levels of objective and subjective career success.

Our study contributes to the literature on entrepreneurial careers. Existing research often assumes that the transition into self-employment is an end in and of itself. Research that examines entrepreneurial entry (and exit) as isolated points in time "tends to overlook commonalities that exist between the transition to entrepreneurship and other forms of career mobility" (Sørensen \& Sharkey: 2014: 331). As a result, researchers have called for a closer examination of the characteristics of pathways associated with entrepreneurial careers (Shepherd, Williams \& Patzelt, 2015), noting that “[...] entrepreneurship scholars have paid relatively little attention to the potential for movement from entrepreneurship back into wage employment or to unemployment" (Burton, Sørensen \& Dobrev, 2016: 241). Our study suggests that a significant degree of heterogeneity exists in self-employment careers. It highlights that self-employment is not the culmination or endpoint of individuals' careers, but

\footnotetext{
${ }^{4}$ This result may be due to a suppression situation. This occurs "when the apparent absence of a relationship between predictor and outcome is spurious, so that the true strong relationship has been either reduced or cancelled because the suppressor variable has not been taken into account" (Johnston, Jones \& Manley, 2018: 1958).
} 
in many cases, a career episode which is embedded into a career trajectory characterized by frequent transitions between self-employment and other states. These results extend the work of Zacher et al. (2012), who also studied patterns of self-employment using SOEP data but operationalized self-employment with four indicators combining several dimensions (farmer vs. other self-employed, full-time vs. part-time), and examined how socio-demographic variables and personality relate to different patterns of self-employment.

Our study also adds to the literature on objective career success of entrepreneurs. Research on the outcomes of self-employment has studied firms far more than individuals, which may explain the relative paucity of research in this area (Lau, Shaffer \& Au, 2007). Existing research that centers on objective career success of self-employed individuals (e.g., Hamilton, 2000) does not take a longitudinal careers perspective. In contrast, by taking a longitudinal careers perspective, our study shows how different patterns of self-employment careers are linked to objective career success and provides a better understanding of objective career success associated with self-employment. Our study advances our understanding of objective career success of different groups of self-employed (Sorgner, Fritsch \& Kritikos, 2017) and the consequences of career change (Wang \& Wanberg, 2017). For instance, we found that gross labor income is higher for persistent compared to intermittent selfemployment career patterns. To contextualize these results, we note that previous studies reported higher incomes for employees compared to self-employed individuals in the amount of 7.5\% (Sorgner, Fritsch \& Kritikos, 2017) or 9\% (Hartog, van Praag \& van der Sluis, 2010), whereas others indicate a premium for self-employment (e.g., 7\% reported by AjayiObe \& Parker, 2005; or 10\% reported by Manso, 2016). Our findings can help explain some of the inconclusive results just cited regarding the objective career success of the selfemployed compared to salaried individuals (Åstebro, 2012). The results show that individuals who engage in self-employment follow different types of career paths, and while the gross 
labor income for persistent self-employment career patterns is higher than for intermittent self-employment career patterns, the gross labor income for necessity self-employment career patterns is lower than for intermittent self-employment career patterns. This suggests that researchers need to pay more attention to career aspects of self-employed individuals when examining objective career success. Our study also finds that the objective career success in persistent self-employment career patterns was significantly higher than in mixed selfemployment career patterns. Previous studies have indicated that focusing on one employment state is crucial for objective career success (Judge, Klinger \& Simon, 2010; Seibert, Kraimer \& Liden, 2001) and our findings are consistent with these works. Overall, our results are consistent with theories of learning and matching which predict that persistence in self-employment leads to higher incomes.

Finally, we contribute to the entrepreneurship literature on subjective career success. We found that persistent self-employment career patterns have the highest job satisfaction among all the clusters. The results showed that job satisfaction for persistent self-employment career patterns is 0.195 higher than for the mixed self-employment career patterns and 0.396 higher than for the intermittent self-employment career patterns on a 0-10 scale. To contextualize these results, we note that prior studies using SOEP data found positive and significant effects regarding job satisfaction for individuals who are self-employed or transitioned from paid employment to self-employment. Specifically, Binder and Coad (2016) examined a sample spanning the years from 1997 to 2010 and found a significant and positive relationship between self-employment and job satisfaction $(b=0.3021)$. Research by van der Zwan, Hessels and Rietveld (2018), based on data covering the 1984 to 2012 period and using a fixed effects linear regression, found that transitioning from paid employment to selfemployment is related to a positive and significant increase in job satisfaction in the following year $(b=0.428)$. Several notable studies based on different data have found the 
following results: Schneck (2014), using data from the European Social Survey (ESS), found that the self-employed are significantly more satisfied with their jobs than employed individuals across Western Europe $(b=0.434)$, although the coefficient for the German subsample was not significant (job satisfaction was measured on a 11-point Likert scale). Work by Andersson (2008), relying on Swedish panel data, found that self-employed individuals report significantly higher job satisfaction than individuals in paid employment (b $=0.621)$, and this significant result holds up in a fixed effects model as well $(b=0.582)$. Job satisfaction in Andersson's (2008) study was measured using a dummy variable. Binder and Coad (2013), using British Household Panel Survey data for the 1996 to 2006 period, found that self-employment is related to significantly higher job satisfaction $(b=0.3268)$. Job satisfaction was measured on a seven-point Likert scale.

Our results provide a more fine-grained understanding of how engaging in different types of self-employment careers relates to job satisfaction. They support the notion of enhanced procedural utility that can be derived from sustained and persistent self-employment (Benz \& Frey, 2008a). This finding enriches prior work which found that self-employed who transition into self-employment from paid employment enjoyed more autonomy and increased job satisfaction during the first three years of self-employment (Binder \& Coad, 2016). We show that the continuous engagement in self-employment is likely to provide individuals with freedom and autonomy that lead to higher job satisfaction. We show that the self-employed can experience higher job satisfaction not only during the first few years of engaging in selfemployment, but also over the course of their career if they pursue self-employment persistently. Our work also highlights the importance of path-dependence in explaining job satisfaction as our results indicate that depending on the type of their career trajectories, selfemployed individuals may experience higher or lower job satisfaction. 
By adopting a careers perspective, our study goes beyond examining each transition across employment states in isolation, enriching the literature that hitherto has focused on transition into self-employment as a discrete event and examined opportunity versus necessity entrepreneurship (Binder \& Coad, 2016), personality traits, and preferences to explain the variation in job satisfaction among the entrepreneurs (Stephan, 2018). With respect to life satisfaction, we found that life satisfaction is highest in persistent selfemployment career patterns compared to all other self-employment career patterns. Our results showed that life satisfaction for persistent self-employment career patterns is 0.180 higher than for the mixed self-employment career patterns and 0.245 higher than for the intermittent self-employment career patterns on a 0-10 scale. To put our results in the context of other SOEP studies, Binder and Coad (2016) found a non-significant relationship between self-employment and life satisfaction. Binder (2017) examined a larger sample and timespan (1984-2015) and found a significant negative relationship between self-employment and life satisfaction $(b=-.07)$. For the subsample of opportunity entrepreneurs, Binder (2017) and Binder and Coad (2016) found a significant positive relationship, while van der Zwan, Hessels and Rietveld (2018) found non-significant effects based on SOEP data. When comparing our results to similar studies that used non-German data, studies by Andersson (2008) based on Swedish data and Binder and Coad (2013) based on British data, found that self-employed individuals have higher levels of life satisfaction than individuals in paid employment $(b=0.384$, and $b=0.0561$ respectively), but fixed effects models in both studies showed no significant differences. Life satisfaction in Andersson (2008) was measured using a dummy variable, while in Binder and Coad (2013), a seven-point Likert scale was used.

Our results are still supported when we control for gross labor income. The inclusion of income in studies that examine subjective career success has been discussed controversially. While income has been shown to impact subjective career success (Stephan, 2018), some 
studies do not include income as a control variable as "it can be hard to disentangle the effect of becoming self-employed from the effect of receiving a lower income on the outcomes" (Andersson, 2008: 218). Our results are consistent with existing research that has found that the magnitude of the relationship between employment state and satisfaction is higher for job satisfaction than life satisfaction (e.g., Binder \& Coad, 2016: Aguilar et al., 2013).

\section{Practical Implications}

Our findings have implications for (aspiring) self-employed individuals. From an income perspective, specialization and persistence in self-employment appears to result in better financial returns than pursuing a mixed career that does not focus on either employment state and might include frequent moves between them. If income is an important factor for considering self-employment, individuals should be aware that focusing on selfemployment should result in higher income over their career. In terms of subjective career success, a persistent focus on self-employment should help individuals achieve higher job satisfaction and, to a lesser extent, higher life satisfaction compared to engaging in other types of entrepreneurial careers. We recognize that transitions between paid employment and self-employment may not be voluntary, as happens in cases where individuals are forced to exit self-employment for lack of financial success (e.g., DeTienne, 2010). Therefore, our recommendations are applicable to individuals who engage in voluntary career transitions.

An important policy implication of our research is the need to provide continuous support to the self-employed to enable them to persist in self-employment and thus reap the monetary and non-monetary benefits of self-employment. This may also involve institutions, e.g., higher education, governments or other initiatives, enabling persistent self-employment by supporting individuals throughout, and not only in the beginning of their career in selfemployment. In many countries, governments provide assistance to those individuals who intend to start their own business (e.g., Busenitz, Gomez \& Spencer, 2000). However, there 
appears to be less institutional support for individuals who are already self-employed. Policymakers should therefore consider providing adequate support for the self-employed beyond the startup phase of firm creation.

\section{Limitations and future research}

As noted, our sample is representative of the German context, which is distinct in terms of institutional, economic and cultural aspects of self-employment (Bergmann \& Sternberg, 2007). Replications with different samples drawn from different contexts would be desirable to increase the generalizability of our results.

Like any other panel surveys, SOEP is affected by panel attrition. Besides the inability to contact participants, reasons for panel attrition often relate to socio-demographic variables such as gender, age, size of household or geographical region of the respondents (Lipps, 2009). Income is only weakly related to attrition in the SOEP panel (Kuhn, 2009). A review of the factors leading to attrition in SOEP (Kroh, Kühne, Siegers \& Belcheva, 2018) does not provide a reason to believe that individuals in self-employment are more strongly affected by attrition, or that successful self-employed individuals are more likely to drop out than unsuccessful ones. Specifically, sample selection bias is not a concern since "employees and self-employed individuals who have stayed in business as well as those who have failed are interviewed repeatedly in each wave" (Nieß \& Biemann, 2014: 1002).

We focused on a particular set of measures for evaluating objective and subjective career success. Another commonly studied measure of objective career success is promotion, which is not applicable in the context of self-employment. Still, future researcher may wish to investigate the relationship between self-employment career patterns and career satisfaction, which is another important measure of subjective career success.

Future research might also examine how different self-employment career patterns are related to organizational survival and success. In this article, we have examined how 
individual self-employment career patterns relate to individual-level outcomes. Future research on self-employment career patterns and organizational survival and success would enable scholars to better document the link between individuals and venture performance.

Finally, our analyses of self-employment careers did not explicitly account for the different types of self-employment, nor incorporated a host of factors that might influence individual decisions to engage in or exit self-employment. We were unable to consider the decision-making processes or motives behind career changes such as security, autonomy or challenge motives (e.g., Douglas \& Shepherd, 2002; Feldman \& Bolino, 2000; Kolvereid, 1996). As a result, our analyses are limited to observable career transitions and cannot clarify the complex processes and decisions that underpin them. Further research that investigates self-employment career patterns accounting for individual motives, incentives or constraints would be informative. Future work that complements our study with other individual-level data could provide for a better understanding of developmental processes relating to entrepreneurial activity (Obschonka \& Silbereisen, 2012). Self-employment career patterns are not uniform, requiring deeper understanding of the factors that shape them over time and affect their success. 


\section{REFERENCES}

Abbott, A. (1990). A primer on sequence methods. Organization Science, 1, 375-392.

Abbott, A. (1995). Sequence analysis: new methods for old ideas. Annual Review of Sociology, 21(1), 93-113.

Aguilar, A. C., Muñoz, T. M. G., \& Moro-Egido, A. I. (2013). Heterogeneous selfemployment and satisfaction in Latin America. Journal of Economic Psychology, 39, 44-61.

Ajayi-Obe, O., \& Parker, S. C. (2005). The changing nature of work among the selfemployed in the 1990s: Evidence from Britain. Journal of Labor Research, 26(3), 501517.

Andersson, P. (2008). Happiness and health: Well-being among the self-employed. The Journal of Socio-Economics, 37, 213-236.

Arthur, M. B., \& Rousseau, D. M. (Eds.). (2001). The boundaryless career: A new employment principle for a new organizational era. Oxford: Oxford University Press.

Arthur, M. B., Khapova, S. N., \& Wilderom, C. P. (2005). Career success in a boundaryless career world. Journal of Organizational Behavior, 26, 177-202.

Åstebro , T., \& Thompson, P. (2011). Entrepreneurs, Jacks of all trades or Hobos?, Research Policy, 40, 637-649.

Åstebro , T., \& Yong, K. (2016). Invention quality and entrepreneurial earnings: the role of prior employment variety. Entrepreneurship Theory and Practice, 40, 381-400.

Åstebro, T. (2012). Returns to entrepreneurship. In: Cumming, D. (ed.): The Oxford Handbook of Entrepreneurial Finance, 45-108. Oxford: Oxford University Press.

Åstebro, T., \& Chen, J. (2014). The entrepreneurial earnings puzzle: Mismeasurement or real?. Journal of Business Venturing, 29(1), 88-105. 
Beck, N., \& Katz, J. N. (1995). What to do (and not to do) with time-series cross-section data. American Political Science Review, 89(3), 634-647.

Benz, M., \& Frey, B. S. (2008a). The value of doing what you like: Evidence from the selfemployed in 23 countries. Journal of Economic Behavior \& Organization, 68, 445-455.

Benz, M., \& Frey, B. S. (2008b). Being independent is a great thing: Subjective evaluations of self-employment and hierarchy. Economica, 75, 362-383.

Bergmann, H., \& Sternberg, R. (2007). The changing face of entrepreneurship in Germany. Small Business Economics, 28, 205-221.

Biemann, T., \& Wolf, J. (2009). Career patterns of top management team members in five countries: an optimal matching analysis. The International Journal of Human Resource Management, 20, 975-991.

Biemann, T., \& Datta, D. K. (2014). Analyzing sequence data: Optimal matching in management research. Organizational Research Methods, 17(1), 51-76.

Biemann, T., Zacher, H., \& Feldman, D. C. (2012). Career patterns: A twenty-year panel study. Journal of Vocational Behavior, 81), 159-170.

Binder, M. (2017). Entrepreneurial success and subjective well-being: Worries about the business explain one's well-being loss from self-employment. SOEPpaper No. 947. Available at SSRN: https://ssrn.com/abstract=3100865

Binder, M., \& Coad, A. (2013). Life satisfaction and self-employment: a matching approach. Small Business Economics, 40(4), 1009-1033.

Binder, M., \& Coad, A. (2016). How satisfied are the self-employed? A life domain view. Journal of Happiness Studies, 17(4), 1409-1433.

Blair-Loy, M. (1999). Career patterns of executive women in finance: An optimal matching analysis. American Journal of Sociology, 104(5), 1346-1397. 
Blanchflower, D. G. (2004). Self-employment: More may not be better. National Bureau of Economic Research.

Blanchflower, D. G., \& Oswald, A. J. (1998). What makes an entrepreneur?. Journal of Labor Economics, 16, 26-60.

Block, J., \& Sandner, P. (2009). Necessity and opportunity entrepreneurs and their duration in self-employment: evidence from German micro data. Journal of Industry, Competition and Trade, 9(2), 117-137.

Boyce, C. J., Wood, A. M., \& Ferguson, E. (2016). Individual differences in loss aversion: Conscientiousness predicts how life satisfaction responds to losses versus gains in income. Personality and Social Psychology Bulletin, 42, 471-484.

Burton, M. D., Sørensen, J. B., \& Dobrev, S. D. (2016). A careers perspective on entrepreneurship. Entrepreneurship Theory and Practice, 40, 237-247.

Busenitz, L. W., Gomez, C., \& Spencer, J. W. (2000). Country institutional profiles: Unlocking entrepreneurial phenomena. Academy of Management Journal, 43(5), 9941003.

Caliendo, M., Fossen, F., \& Kritikos, A. S. (2014). Personality characteristics and the decisions to become and stay self-employed. Small Business Economics, 42, 787-814.

Campbell, B. A. (2013). Earnings effects of entrepreneurial experience: Evidence from the semiconductor industry. Management Science, 59(2), 286-304.

Carter, N. M., Gartner, W. B., Shaver, K. G., \& Gatewood, E. J. (2003). The career reasons of nascent entrepreneurs. Journal of Business Venturing, 18(1), 13-39.

Carter, S. (2011). The rewards of entrepreneurship: Exploring the incomes, wealth, and economic well-being of entrepreneurial households. Entrepreneurship Theory and Practice, 35, 39-55. 
Charrad, M., Ghazzali, N., Boiteau, V., \& Niknafs, A. (2014). NbClust: An examination of indices for determining the number of clusters. Journal of Statistical Software, 61, 1-36.

Coad, A., \& Binder, M. (2014). Causal linkages between work and life satisfaction and their determinants in a structural VAR approach. Economics Letters, 124, 263-268.

Cope, J. (2005). Toward a dynamic learning perspective of entrepreneurship. Entrepreneurship Theory and Practice, 29(4), 373-397.

Daly, M. (2015). The long term returns of attempting self-employment with regular employment as a fall back option. Labour Economics, 35, 26-52.

Delmar, F., \& Davidsson, P. (2000). Where do they come from? Prevalence and characteristics of nascent entrepreneurs. Entrepreneurship \& Regional Development, 12(1), 1-23.

DeTienne, D. R. (2010). Entrepreneurial exit as a critical component of the entrepreneurial process: Theoretical development. Journal of Business Venturing, 25(2), 203-215.

Dlouhy, K., \& Biemann, T. (2015). Optimal matching analysis in career research: A review and some best-practice recommendations. Journal of Vocational Behavior, 90, 163-173.

Douglas, E. J., \& Shepherd, D. A. (2002). Self-employment as a career choice: Attitudes, entrepreneurial intentions, and utility maximization. Entrepreneurship Theory and Practice, 26, 81-90.

Dries, N., Van Acker, F., \& Verbruggen, M. (2012). How 'boundaryless' are the careers of high potentials, key experts and average performers? Journal of Vocational Behavior, $81,271-279$.

Earl, J. K., \& Bright, J. E. (2007). The relationship between career decision status and important work outcomes. Journal of Vocational Behavior, 71(2), 233-246. 
Elder, G. H., Johnson, M. K., \& Crosnoe, R. (2003). The emergence and development of life course theory. In: Mortimer, J.T., \& Shanahan, M.J. (eds.). Handbook of the Life Course. Boston: Springer, 3-19.

Erdogan, B., Bauer, T. N., Truxillo, D. M., \& Mansfield, L. R. (2012). Whistle while you work: A review of the life satisfaction literature. Journal of Management, 38(4), 10381083.

Evans, D. S., \& Leighton, L. S. (1989). Some empirical aspects of entrepreneurship. American Economic Review, 79(3): 519-535.

Failla, V., Melillo, F., \& Reichstein, T. (2017). Entrepreneurship and employment stabilityJob matching, labour market value, and personal commitment. Journal of Business Venturing, 32(2), 162-177.

Feldman, D. C., \& Bolino, M. C. (2000). Career patterns of the self-employed: Career motivations and career outcomes. Journal of Small Business Management, 38, 53-67.

Feldman, D. C., \& Ng, T. W. (2007). Careers: Mobility, embeddedness, and success. Journal of Management, 33(3), 350-377.

Fisher, G. G., Matthews, R. A., \& Gibbons, A. M. (2016). Developing and investigating the use of single-item measures in organizational research. Journal of Occupational Health Psychology, 21, 3-23.

Flap, H., \& Völker, B. (2001). Goal specific social capital and job satisfaction: Effects of different types of networks on instrumental and social aspects of work. Social Networks, 23(4), 297-320.

Frey, B. S., Benz, M., \& Stutzer, A. (2004). Introducing procedural utility: Not only what, but also how matters. Journal of Institutional and Theoretical Economics, 160(3), 377-401.

Fritsch, M., \& Rusakova, A. (2010). Personality traits, self-employment, and professions. SOEPpaper No. 343. Available at: http://dx.doi.org/10.2139/ssrn.1736576. 
Fuchs-Schündeln, N. (2009). On preferences for being self-employed. Journal of Economic Behavior \& Organization, 71, 162-171.

Gabadinho, A., Ritschard, G., Mueller, N. S., \& Studer, M. (2011). Analyzing and visualizing state sequences in R with TraMineR. Journal of Statistical Software, 40(4), 1-37.

Gati, I., Asulin-Peretz, L., \& Fisher, A. (2012). Emotional and personality-related career decision-making difficulties: A 3-year follow-up. The Counseling Psychologist, 40, 6 27.

Gerstorf, S., \& Schupp, J. (2016). SOEP wave report 2015. Deutsches Institut für Wirtschaftsforschung (DIW), Berlin, Available at: http://hdl.handle.net/10419/148021

Gompers, P., Kovner, A., Lerner, J., \& Scharfstein, D. (2010). Performance persistence in entrepreneurship. Journal of Financial Economics, 96(1), 18-32.

Greene, W. H. (2000). Econometric Analysis, 4th edition. Upper Saddle River, NJ: Prentice Hall.

Hair, J. F., Anderson, R. E., Tatham, R. L., \& Black, W. C. (1998). Multivariate Data Analysis. Upper Saddle River, NJ: Prentice Hall.

Hamilton, B. H. (2000). Does entrepreneurship pay? An empirical analysis of the returns to self-employment. Journal of Political Economy, 108, 604-631.

Hartog, J., Van Praag, M., \& Van Der Sluis, J. (2010). If you are so smart, why aren't you an entrepreneur? Returns to cognitive and social ability: Entrepreneurs versus employees. Journal of Economics \& Management Strategy, 19(4), 947-989.

Heller, D., Watson, D., \& Ilies, R. (2004). The role of person versus situation in life satisfaction: a critical examination. Psychological Bulletin, 130, 574-600.

Heslin, P. A. (2005). Conceptualizing and evaluating career success. Journal of Organizational Behavior, 26, 113-136. 
Hessels, J., Arampatzi, E., van der Zwan, P., \& Burger, M. (2018). Life satisfaction and selfemployment in different types of occupations. Applied Economics Letters, 25, 734740.

Hetschko, C. (2016). On the misery of losing self-employment. Small Business Economics, 47(2), 461-478.

Hsu, D. K., Shinnar, R. S., Powell, B. C., \& Coffey, B. S. (2017). Intentions to reenter venture creation: The effect of entrepreneurial experience and organizational climate. International Small Business Journal, 35(8), 928-948.

Hülür, G., Heckhausen, J., Hoppmann, C. A., Infurna, F. J., Wagner, G. G., Ram, N., \& Gerstorf, D. (2017). Levels of and changes in life satisfaction predict mortality hazards: Disentangling the role of physical health, perceived control, and social orientation. Psychology and Aging, 32, 507-520.

Hundley, G. (2001). Why and when are the self-employed more satisfied with their work? Industrial Relation. A Journal of Economy and Society, 40, 293-316.

Hytti, U., Kautonen, T., \& Akola, E. (2013). Determinants of job satisfaction for salaried and self-employed professionals in Finland. The International Journal of Human Resource Management, 24(10), 2034-2053.

Hyytinen, A., \& Rouvinen, P. (2008). The labour market consequences of self-employment spells: European evidence. Labour Economics, 15(2), 246-271.

Jaensch, V. K., Hirschi, A., \& Freund, P. A. (2015). Persistent career indecision over time: Links with personality, barriers, self-efficacy, and life satisfaction. Journal of Vocational Behavior, 91, 122-133.

Jayawarna, D., Rouse, J., \& Kitching, J. (2013). Entrepreneur motivations and life course. International Small Business Journal, 31, 34-56. 
Johnston, R., Jones, K., \& Manley, D. (2018). Confounding and collinearity in regression analysis: a cautionary tale and an alternative procedure, illustrated by studies of British voting behaviour. Quality \& Quantity, 52(4), 1957-1976.

Joseph, D., Boh, W. F., Ang, S., \& Slaughter, S. A. (2012). The career paths less (or more) traveled: A sequence analysis of IT career histories, mobility patterns, and career success. MIS Quarterly, 36(2), 427-452.

Judge, T. A., Klinger, R. L., \& Simon, L. S. (2010). Time is on my side: Time, general mental ability, human capital, and extrinsic career success. Journal of Applied Psychology, 95(1), 92-107.

Kakwani, N. C. (1967). The unbiasedness of Zellner's seemingly unrelated regression equations estimators. Journal of the American Statistical Association, 62(317), 141142.

Kampkötter, P. (2017). Performance appraisals and job satisfaction. The International Journal of Human Resource Management, 28(5), 750-774.

Kattenbach, R., Schneidhofer, T. M., Lücke, J., Latzke, M., Loacker, B., Schramm, F., \& Mayrhofer, W. (2014). A quarter of a century of job transitions in Germany. Journal of Vocational Behavior, 84(1), 49-58.

Kolvereid, L. (1996). Organizational employment versus self-employment: Reasons for career choice intentions. Entrepreneurship Theory and Practice, 20(3), 23-31.

Kovalenko, M., \& Mortelmans, D. (2014). Does career type matter? Outcomes in traditional and transitional career patterns. Journal of Vocational Behavior, 85(2), 238-249.

Kroh, M., Kühne, S., Siegers, R., \& Belcheva, V. (2018). SOEP-Core-Documentation of sample sizes and panel attrition (1984 until 2016) (No. 480). SOEP Survey Papers. Available at: https://www.diw.de/documents/publikationen/73/diw_01.c.579464.de/diw_ssp0480.pdf 
Kuhn, U. (2009). Attrition analysis of income data. Swiss Household Panel, FORS, SHP Working Paper 2_09, 1-14. Available at: https://core.ac.uk/download/pdf/18165309.pdf Lange, T. (2012). Job satisfaction and self-employment: autonomy or personality?. Small Business Economics, 38(2), 165-177.

Lau, V. P., Shaffer, M. A., \& Au, K. (2007). Entrepreneurial career success from a Chinese perspective: conceptualization, operationalization, and validation. Journal of International Business Studies, 38(1), 126-146.

Lipps, O. (2009). Attrition of households and individuals in panel surveys. SOEPpaper No. 164, available at SSRN: https://ssrn.com/abstract=1367371

Lucas, R. E., \& Donnellan, M. B. (2012). Estimating the reliability of single-item life satisfaction measures: Results from four national panel studies. Social Indicators Research, 105(3), 323-331.

Luzzi, A., \& Sasson, A. (2016). Individual entrepreneurial exit and earnings in subsequent paid employment. Entrepreneurship Theory and Practice, 40(2), 401-420.

Manso, G. (2016). Experimentation and the Returns to Entrepreneurship. The Review of Financial Studies, 29(9), 2319-2340.

Marshall, D. R. (2016). From employment to entrepreneurship and back: A legitimate boundaryless view or a bias-embedded mindset?. International Small Business Journal, 34(5), 683-700.

Millán, J. M., Hessels, J., Thurik, R., \& Aguado, R. (2013). Determinants of job satisfaction: a European comparison of self-employed and paid employees. Small Business Economics, 40(3), 651-670.

Minniti, M., \& Bygrave, W. (2001). A dynamic model of entrepreneurial learning. Entrepreneurship Theory and Practice, 25(3), 5-16. 
Ng, T. W., \& Feldman, D. C. (2014). Subjective career success: A meta-analytic review. Journal of Vocational Behavior, 85(2), 169-179.

Ng, T. W., Eby, L. T., Sorensen, K. L. \& Feldman, D. C. (2005). Predictors of objective and subjective career success: A meta-analysis. Personnel Psychology, 58(2), 367-408.

Nieß, C., \& Biemann, T. (2014). The role of risk propensity in predicting self-employment. Journal of Applied Psychology, 99(5), 1000-1009.

Nikolaev, B., Boudreaux, C. J., \& Wood, M. (in press). Entrepreneurship and subjective wellbeing: The mediating role of psychological functioning. Entrepreneurship Theory and Practice, https://doi.org/10.1177/1042258719830314

Obschonka, M., \& Silbereisen, R. K. (2012). Entrepreneurship from a developmental science perspective. International Journal of Developmental Science, 6(3-4), 107-115.

Obschonka, M., Silbereisen, R. K. \& Schmitt-Rodermund, E. (2010). Entrepreneurial intention as developmental outcome. Journal of Vocational Behavior, 77(1), 63-72.

Obschonka, M., Silbereisen, R. K., Schmitt-Rodermund, E. \& Stuetzer, M. (2011). Nascent entrepreneurship and the developing individual: Early entrepreneurial competence in adolescence and venture creation success during the career. Journal of Vocational Behavior, 79(1), 121-133.

Patel, P. C. \& Thatcher, S. M. (2014). Sticking it out: Individual attributes and persistence in self-employment. Journal of Management, 40(7), 1932-1979.

Pavot, W., \& Diener, E. (1993). Review of the satisfaction with life scale. Psychological Assessment, 5(2), 164-172.

Pentland, B. T. (2003). Sequential variety in work processes. Organization Science, 14(5), 528-540.

Phillips, B. D. \& Kirchhoff, B. A. (1989). Formation, growth and survival; small firm dynamics in the US economy. Small Business Economics, 1(1), 65-74. 
Przepiorka, A. M. (2017). Psychological determinants of entrepreneurial success and lifesatisfaction. Current Psychology, 36(2), 304-315.

Riza, S., Ganzach, Y., \& Liu, Y. (2018). Time and job satisfaction: A longitudinal study of the differential roles of age and tenure. Journal of Management, 44(7), 2558-2579.

Rocha, V., Carneiro, A., \& Varum, C. A. (2015). Entry and exit dynamics of nascent business owners. Small Business Economics, 45(1), 63-84.

Rohrer, J. M., Richter, D., Brümmer, M., Wagner, G. G., \& Schmukle, S. C. (2018). Successfully Striving for Happiness: Socially Engaged Pursuits Predict Increases in Life Satisfaction. Psychological Science, 29(8), 1291-1298.

Ryan, R. M., \& Deci, E. L. (2000). Self-determination theory and the facilitation of intrinsic motivation, social development, and well-being. American Psychologist, 55(1), 68-78.

Salanova, M., Bakker, A. B., \& Llorens, S. (2006). Flow at work: Evidence for an upward spiral of personal and organizational resources. Journal of Happiness Studies, 7(1), 122.

Savickas, M. (2001). A developmental perspective on vocational behavior: Career patterns, salience, and themes. International Journal for Educational and Vocational Guidance, $1(1-2), 49-57$.

Schilling, O. K. (2005). Cohort-and age-related decline in elder's life satisfaction: is there really a paradox?. European Journal of Ageing, 2(4), 254-263.

Schjoedt, L., \& Shaver, K. G. (2007). Deciding on an entrepreneurial career: A test of the pull and push hypotheses using the panel study of entrepreneurial dynamics data. Entrepreneurship Theory and Practice, 31(5), 733-752.

Schneck, S. (2014). Why the self-employed are happier: Evidence from 25 European countries. Journal of Business Research, 67(6), 1043-1048. 
Seibert, S. E., Kraimer, M. L., \& Liden, R. C. (2001). A social capital theory of career success. Academy of Management Journal, 44(2), 219-237.

Sevä, I. J., Larsson, D., \& Strandh, M. (2016). The prevalence, characteristics and well-being of 'necessity 'self-employed and 'latent' entrepreneurs: findings from Sweden. International Journal of Entrepreneurship and Small Business, 28(1), 58-77.

Sevä, I. J., Vinberg, S., Nordenmark, M., \& Strandh, M. (2016). Subjective well-being among the self-employed in Europe: Macroeconomy, gender and immigrant status. Small Business Economics, 46(2), 239-253.

Shane, S., Locke, E. A., \& Collins, C. J. (2003). Entrepreneurial motivation. Human Resource Management Review, 13(2), 257-279.

Shepherd, D. A., Williams, T. A., \& Patzelt, H. (2015). Thinking about entrepreneurial decision making: Review and research agenda. Journal of Management, 41(1), 11-46.

Shi, W. S., \& Prescott, J. E. (2011). Sequence patterns of firms' acquisition and alliance behaviour and their performance implications. Journal of Management Studies, 48(5), 1044-1070.

Shir, N., Nikolaev, B. N., \& Wincent, J. (2019). Entrepreneurship and well-being: The role of psychological autonomy, competence, and relatedness. Journal of Business Venturing, 34(5), 105875.

Sørensen, J. B., \& Sharkey, A. J. (2014). Entrepreneurship as a mobility process. American Sociological Review, 79(2), 328-349.

Sørensen, J. B., \& Fassiotto, M. A. (2011). Organizations as fonts of entrepreneurship. Organization Science, 22(5), 1322-1331.

Sorgner, A., Fritsch, M., \& Kritikos, A. (2017). Do entrepreneurs really earn less?. Small Business Economics, 49(2), 251-272. 
Souitaris, V., Zerbinati, S., \& Al-Laham, A. (2007). Do entrepreneurship programmes raise entrepreneurial intention of science and engineering students? The effect of learning, inspiration and resources. Journal of Business Venturing, 22(4), 566-591.

Stephan, U. (2018). Entrepreneurs' mental health and well-being: A review and research agenda. Academy of Management Perspectives, 32(3), 290-322.

Stephan, U., \& Roesler, U. (2010). Health of entrepreneurs versus employees in a national representative sample. Journal of Occupational and Organizational Psychology, 83(3), 717-738.

Studer, M., \& Ritschard, G. (2016). What matters in differences between life trajectories: A comparative review of sequence dissimilarity measures. Journal of the Royal Statistical Society: Series A (Statistics in Society), 179(2), 481-511.

Timmons, J.A. (1990). New venture creation: Entrepreneurship in the 1990s. Homewood, IL: Irwin.

Van der Zwan, P., Hessels, J., \& Rietveld, C. A. (2018). Self-employment and satisfaction with life, work, and leisure. Journal of Economic Psychology, 64, 73-88.

Van Gelderen, M., \& Jansen, P. (2006). Autonomy as a start-up motive. Journal of Small Business and Enterprise Development, 13(1), 23-32.

Van Stel, A., \& de Vries, N. (2015). The economic value of different types of solo selfemployed: A review. In: Burke, A. (Ed): The Handbook of Research on Freelancing and Self-Employment. Ch. 7, 77-84.

VandenHeuvel, A., \& Wooden, M. (1997). Self-employed contractors and job satisfaction. Journal of Small Business Management, 35(3), 11.

Vinkenburg, C. J., \& Weber, T. (2012). Managerial career patterns: A review of the empirical evidence. Journal of Vocational Behavior, 80(3), 592-607. 
Wagner, G. G., Frick, J. R., \& Schupp, J. (2007). The German Socio-Economic Panel Study (SOEP) - Evolution, Scope and Enhancements. SOEPpaper No. 1. Available at http://dx.doi.org/10.2139/ssrn.1028709.

Wang, M., \& Wanberg, C. R. (2017). 100 years of applied psychology research on individual careers: From career management to retirement. Journal of Applied Psychology, 102(3), 546.

Wanous, J. P., \& Hudy, M. J. (2001). Single-item reliability: a replication and extension. Organizational Research Methods, 4(4), 361-375.

Wanous, J. P., Reichers, A. E., \& Hudy, M. J. (1997). Overall job satisfaction: how good are single-item measures? Journal of Applied Psychology, 82(2), 247-252.

Weiss, H. M. (2002). Deconstructing job satisfaction: Separating evaluations, beliefs and affective experiences. Human Resource Management Review, 12(2), 173-194.

Wennberg, K., \& DeTienne, D. R. (2014). What do we really mean when we talk about “exit"? A critical review of research on entrepreneurial exit. International Small Business Journal, 32(1), 4-16.

Westhead, P., Ucbasaran, D., \& Wright, M. (2005). Decisions, actions, and performance: do novice, serial, and portfolio entrepreneurs differ? Journal of Small Business Management, 43(4), 393-417.

Wortman, J., \& Lucas, R. E. (2016). Spousal similarity in life satisfaction before and after divorce. Journal of Personality and Social Psychology, 110(4), 625-633.

Zacher, H., Biemann, T., Gielnik, M. M., \& Frese, M. (2012). Patterns of entrepreneurial career development: An optimal matching analysis approach. International Journal of Developmental Science, 6(3-4), 177-187.

Zbierowski, P. (2014). Well-being of entrepreneurs-international comparison based on GEM data. Journal of Positive Management, 5(4), 89-100. 
FIGURE 1

Sequence Index Plots for All Clusters

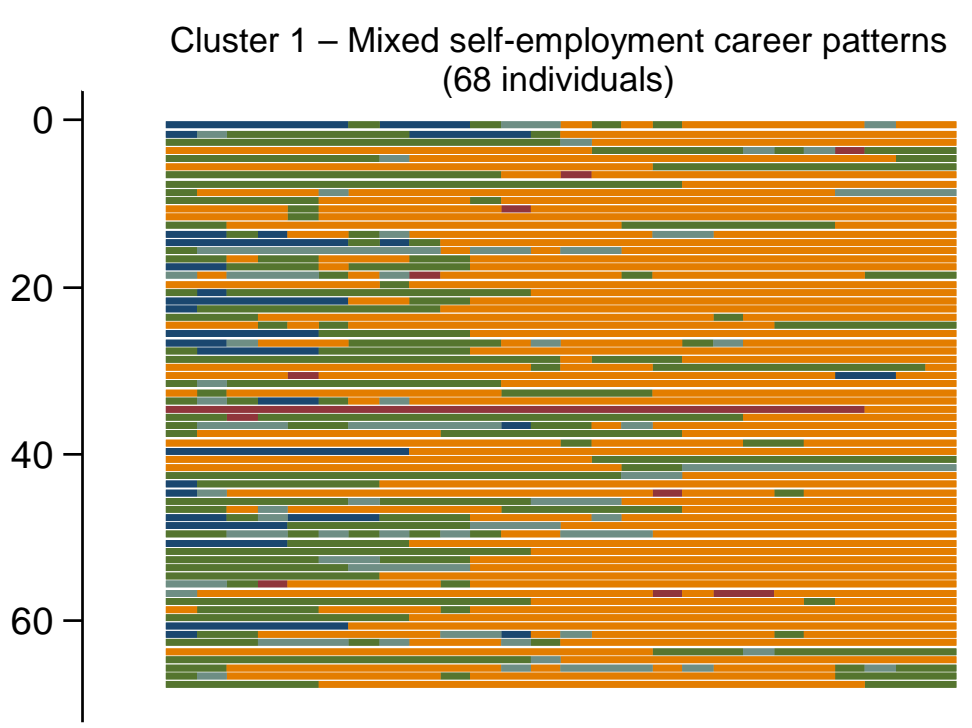

Cluster 3 - Necessity self-employment career patterns (59 individuals)

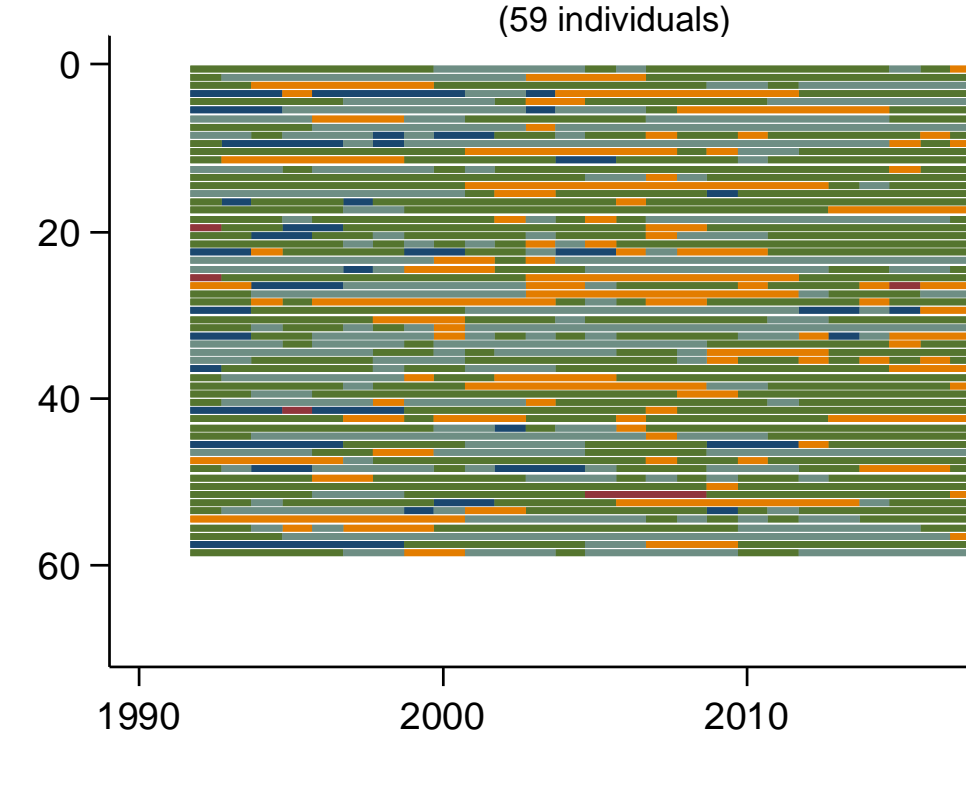

Cluster 2 - Intermittent self-employment career patterns (49 individuals)

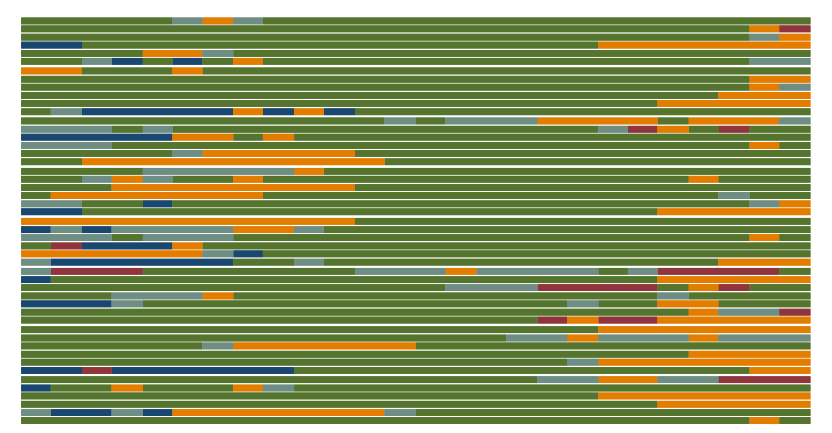

Cluster 4 - Persistent self-employment career patterns (29 individuals)

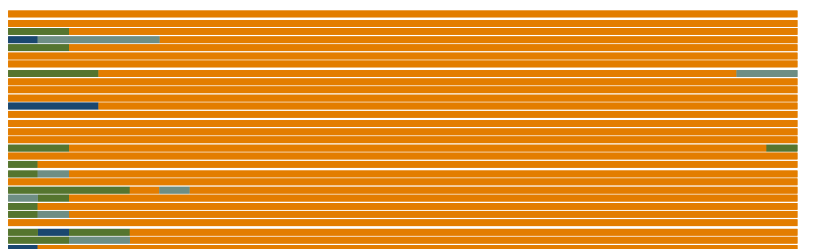

Training

$\square$ Other

$\square$ Paid Employment

Self-Employment

Unemployment 
FIGURE 2

Gross Labor Income by Self-Employment Patterns

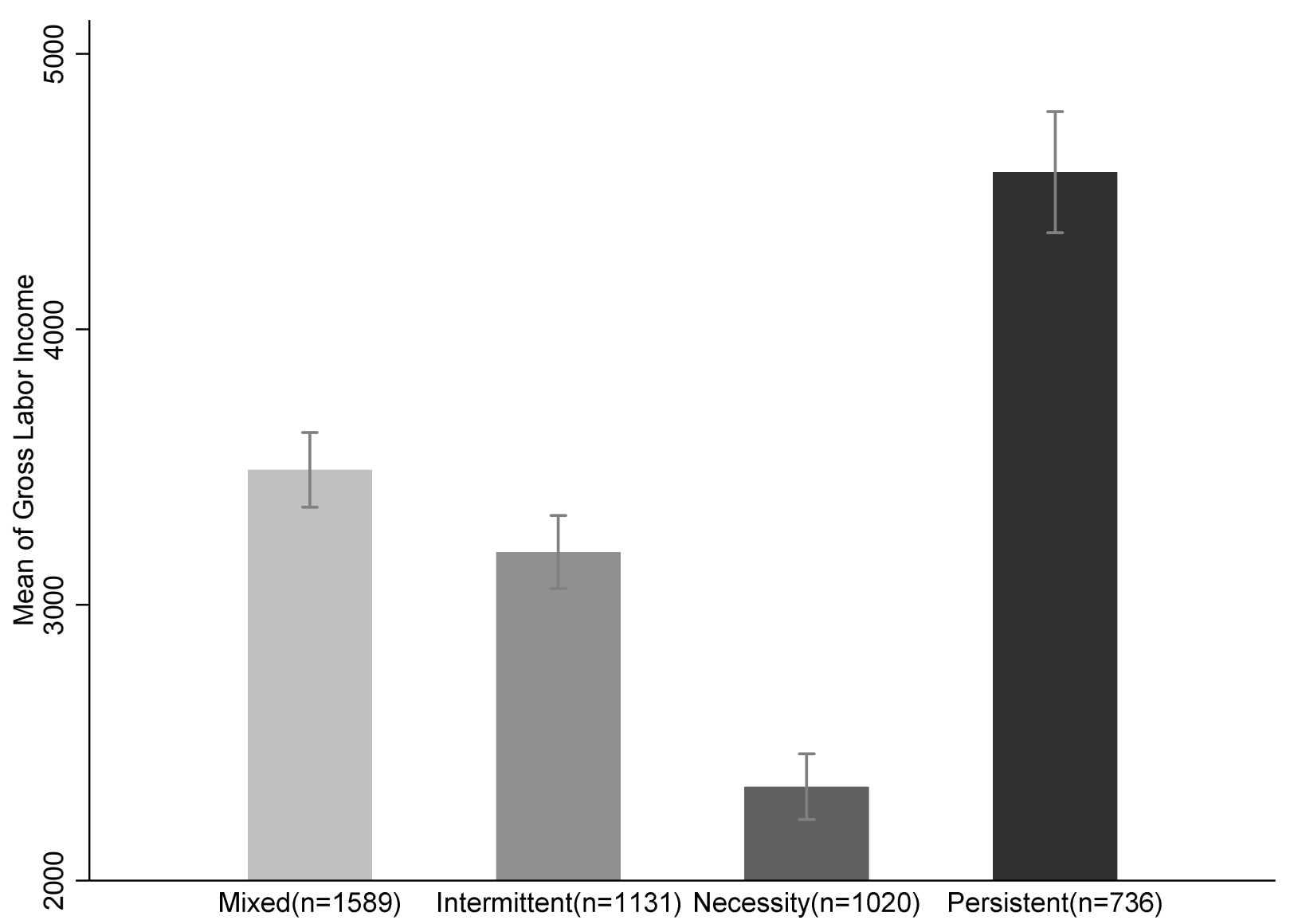

95\% confidence intervals below and above the mean are indicated by lines on the top of each bar. 
FIGURE 3

Job Satisfaction by Self-Employment Patterns

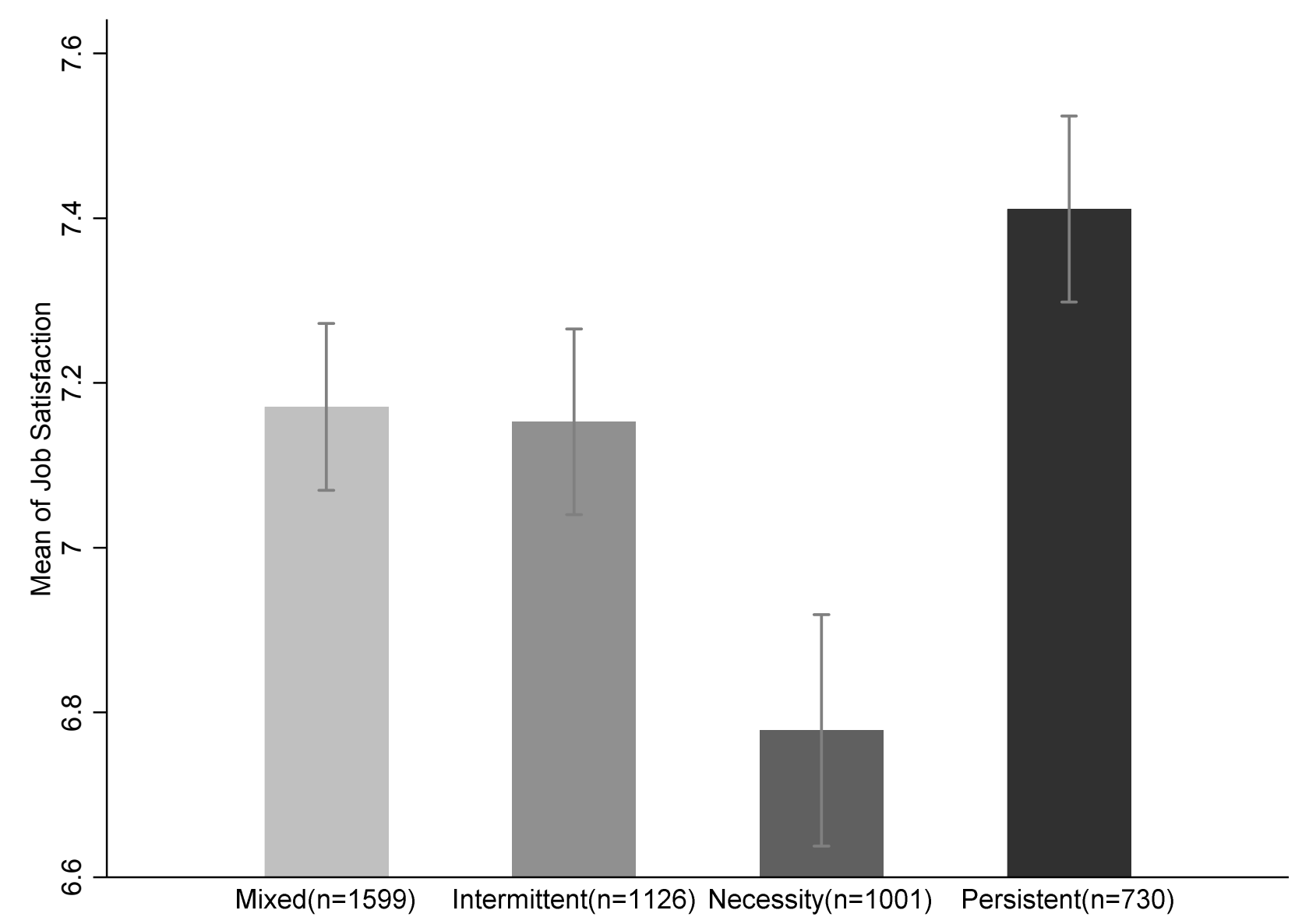

$95 \%$ confidence intervals below and above the mean are indicated by lines on the top of each bar. 
FIGURE 4

Life Satisfaction by Self-Employment Patterns

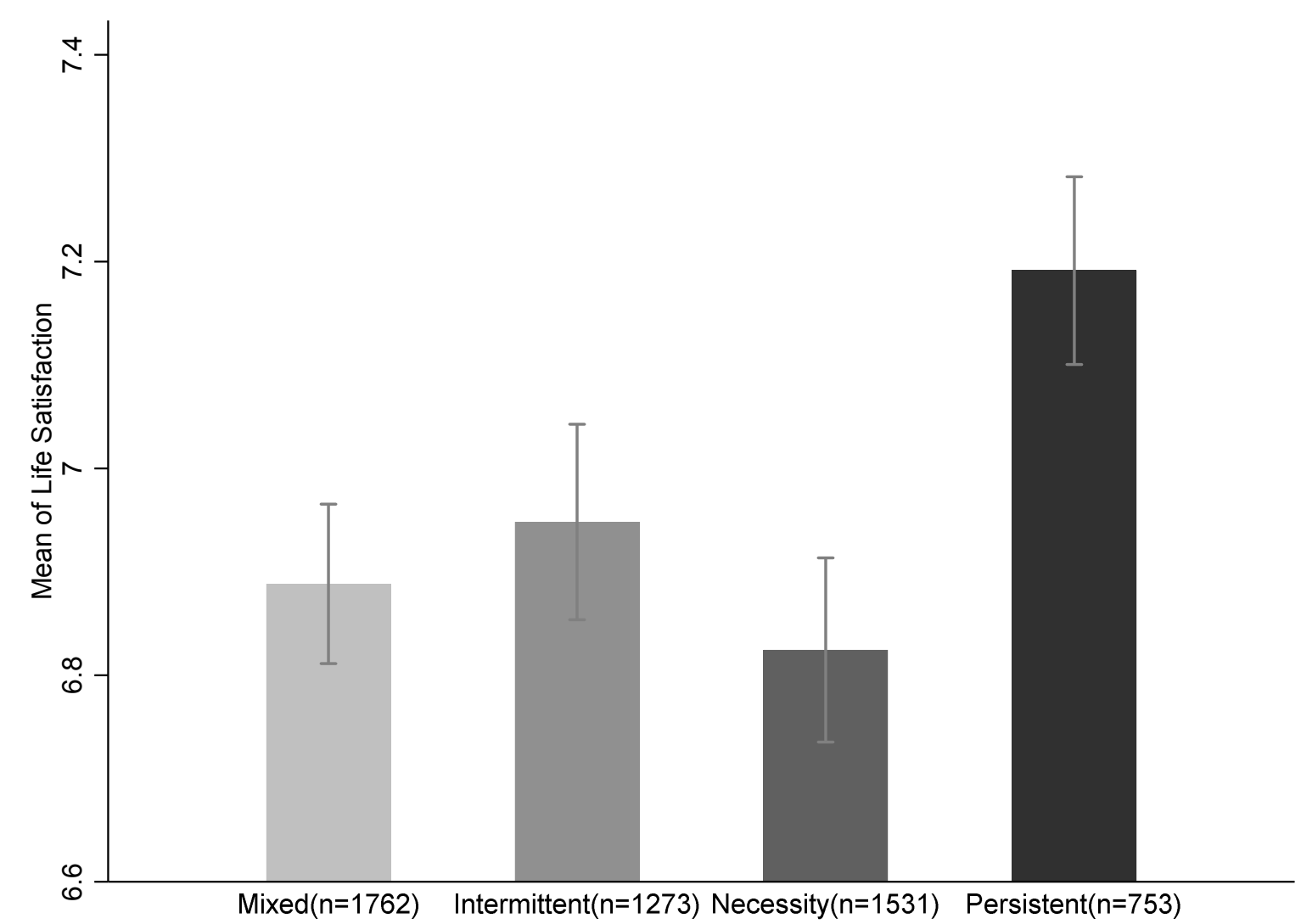

95\% confidence intervals below and above the mean are indicated by lines on the top of each bar. 
TABLE 1

Descriptive Statistics and Pairwise Correlations

\begin{tabular}{|c|c|c|c|c|c|c|c|c|c|c|c|c|c|c|c|}
\hline & & Obs & Mean & $\begin{array}{l}\text { Std. } \\
\text { Dev. }\end{array}$ & Min & $\operatorname{Max}$ & 1 & 2 & 3 & 4 & 5 & 6 & 7 & 8 & 9 \\
\hline 1. & Gross labor income & 4,476 & 3330.83 & 2624.61 & 0 & 28439.75 & 1.00 & & & & & & & & \\
\hline 2. & Job satisfaction & 4,456 & 7.12 & 2.02 & 0 & 10 & 0.17 & 1.00 & & & & & & & \\
\hline 3. & Life satisfaction & 5,319 & 6.93 & 1.66 & 0 & 10 & 0.22 & 0.51 & 1.00 & & & & & & \\
\hline 4. & Age & 5,330 & 43.70 & 10.82 & 17 & 78 & 0.06 & -0.06 & -0.04 & 1.00 & & & & & \\
\hline 5 . & Number of children & 5,330 & 0.81 & 1.02 & 0 & 6 & -0.02 & 0.07 & 0.07 & -0.28 & 1.00 & & & & \\
\hline 6. & Educational attainment & 5,310 & 13.62 & 3.01 & 7 & 18 & 0.21 & 0.02 & 0.10 & 0.13 & 0.05 & 1.00 & & & \\
\hline 7. & $\begin{array}{l}\text { Full-time work } \\
\text { experience }\end{array}$ & 5,330 & 16.14 & 11.35 & 0 & 55.6 & 0.22 & -0.02 & -0.01 & 0.76 & -0.34 & 0.00 & 1.00 & & \\
\hline 8 . & $\begin{array}{l}\text { Part-time work } \\
\text { experience }\end{array}$ & 5,330 & 2.53 & 4.14 & 0 & 27 & -0.25 & -0.02 & -0.06 & 0.24 & 0.02 & -0.07 & -0.26 & 1.00 & \\
\hline 9. & Satisfaction with health & 5,322 & 6.96 & 1.98 & 0 & 10 & 0.12 & 0.38 & 0.51 & -0.21 & 0.12 & 0.09 & -0.11 & -0.14 & 1.00 \\
\hline
\end{tabular}

Note: For Gross labor income, we report non-transformed values. 
TABLE 2

Gross Labor Income, Job Satisfaction and Life Satisfaction According to Clusters

\begin{tabular}{|c|c|c|c|c|c|c|c|c|c|c|c|c|c|c|c|c|c|c|c|c|}
\hline \multirow[b]{2}{*}{ Variable } & \multicolumn{5}{|c|}{ Cluster: Mixed } & \multicolumn{5}{|c|}{ Cluster: Intermittent } & \multicolumn{5}{|c|}{ Cluster: Necessity } & \multicolumn{5}{|c|}{ Cluster: Persistent } \\
\hline & Obs. & Mean & $\begin{array}{l}\text { Std. } \\
\text { Dev. }\end{array}$ & Min & $\operatorname{Max}$ & Obs. & Mean & $\begin{array}{l}\text { Std. } \\
\text { Dev. }\end{array}$ & Min & Max & Obs. & Mean & $\begin{array}{l}\text { Std. } \\
\text { Dev. }\end{array}$ & Min & $\operatorname{Max}$ & Obs. & Mean & $\begin{array}{l}\text { Std. } \\
\text { Dev. }\end{array}$ & Min & $\operatorname{Max}$ \\
\hline $\begin{array}{c}\text { Gross } \\
\text { labor } \\
\text { income }\end{array}$ & 1589 & 3490.62 & 2759.92 & 0 & 28439.75 & 1131 & 3192.38 & 2280.31 & 0 & 19833.00 & 1020 & 2340.82 & 1940.96 & 0 & 25723.97 & 736 & 4570.67 & 3046.65 & 0 & 21713.58 \\
\hline $\begin{array}{c}\text { Job } \\
\text { satisfaction }\end{array}$ & 1599 & 7.17 & 2.06 & 0 & 10 & 1126 & 7.15 & 1.93 & 0 & 10 & 1001 & 6.78 & 2.27 & 0 & 10 & 730 & 7.41 & 1.56 & 0 & 10 \\
\hline $\begin{array}{c}\text { Life } \\
\text { satisfaction }\end{array}$ & 1762 & 6.89 & 1.65 & 0 & 10 & 1273 & 6.95 & 1.72 & 0 & 10 & 1531 & 6.82 & 1.78 & 0 & 10 & 753 & 7.19 & 1.27 & 2 & 10 \\
\hline
\end{tabular}


TABLE 3

Results of Regression Analyses (DV: Gross Labor Income)

\begin{tabular}{|c|c|c|c|c|c|c|}
\hline & \multicolumn{3}{|c|}{ Model 1} & \multicolumn{3}{|c|}{ Model 2} \\
\hline & Coef. & & S.E. & Coef. & & S.E. \\
\hline Gender & -0.213 & $* * *$ & 0.024 & -0.183 & $* * *$ & 0.025 \\
\hline Age & -0.028 & $* * *$ & 0.003 & -0.030 & $* * *$ & 0.003 \\
\hline Marital status & -0.049 & $*$ & 0.027 & -0.043 & & 0.027 \\
\hline Number of children & 0.045 & $* * *$ & 0.011 & 0.039 & $* * *$ & 0.011 \\
\hline Educational attainment & 0.112 & $* * *$ & 0.004 & 0.111 & $* * *$ & 0.004 \\
\hline Full-time work experience & 0.041 & $* * *$ & 0.003 & 0.042 & $* * *$ & 0.003 \\
\hline Part-time work experience & 0.010 & $* *$ & 0.004 & 0.013 & $* * *$ & 0.005 \\
\hline Employment level (part-time) & -0.249 & $* * *$ & 0.022 & -0.250 & $* * *$ & 0.022 \\
\hline Employment level (not working) & -0.564 & $* * *$ & 0.071 & -0.564 & $* * *$ & 0.072 \\
\hline Job change (not applicable) & 0.537 & & 0.608 & 0.530 & & 0.605 \\
\hline Job change (no job change) & 0.583 & & 0.609 & 0.567 & & 0.605 \\
\hline Satisfaction with health & 0.010 & $* * *$ & 0.004 & 0.011 & $* * *$ & 0.004 \\
\hline Region & 0.393 & $* * *$ & 0.023 & 0.397 & $* * *$ & 0.023 \\
\hline Intercept & 6.032 & $* * *$ & 0.612 & & & \\
\hline Intercept (Base level: Mixed) & & & & 6.145 & $* * *$ & 0.609 \\
\hline Intercept (Base level: Intermittent) & & & & 6.091 & $* * *$ & 0.609 \\
\hline Intercept (Base level: Necessity) & & & & 6.039 & $* * *$ & 0.609 \\
\hline Intercept (Base level: Persistent) & & & & 6.264 & $* * *$ & 0.610 \\
\hline Intermittent (Base level: Mixed) & & & & -0.054 & $* *$ & 0.026 \\
\hline Necessity (Base level: Mixed) & & & & -0.106 & $* * *$ & 0.034 \\
\hline Persistent (Base level: Mixed) & & & & 0.119 & $* * *$ & 0.031 \\
\hline Mixed (Base level: Intermittent) & & & & 0.054 & $* *$ & 0.026 \\
\hline Necessity (Base level: Intermittent) & & & & -0.052 & $*$ & 0.031 \\
\hline Persistent (Base level: Intermittent) & & & & 0.173 & $* * *$ & 0.029 \\
\hline Mixed (Base level: Necessity) & & & & 0.106 & $* * *$ & 0.034 \\
\hline Intermittent (Base level: Necessity) & & & & 0.052 & $*$ & 0.031 \\
\hline Persistent (Base level: Necessity) & & & & 0.225 & $* * *$ & 0.035 \\
\hline Mixed (Base level: Persistent) & & & & -0.119 & $* * *$ & 0.031 \\
\hline Intermittent (Base level: Persistent) & & & & -0.173 & $* * *$ & 0.029 \\
\hline Necessity (Base level: Persistent) & & & & -0.225 & $* * *$ & 0.035 \\
\hline Observations & 4408 & & & 4408 & & \\
\hline Wald chi2 & 2279.95 & $* * *$ & & 2390.54 & $* * *$ & \\
\hline
\end{tabular}

$*, * *$, and $* * *$ denote significance at 10,5 , and $1 \%$ levels, respectively. 
TABLE 4

Results of Regression Analyses (DV: Job Satisfaction)

\begin{tabular}{|c|c|c|c|c|c|c|}
\hline & \multicolumn{3}{|c|}{ Model 1} & \multicolumn{3}{|c|}{ Model 2} \\
\hline & Coef. & & S.E. & Coef. & & S.E \\
\hline Gender & 0.411 & $* * *$ & 0.077 & 0.483 & $* * *$ & 0.077 \\
\hline Age & -0.033 & $* * *$ & 0.007 & -0.034 & $* * *$ & 0.008 \\
\hline Marital status & -0.103 & & 0.073 & -0.066 & & 0.072 \\
\hline Number of children & 0.056 & $*$ & 0.030 & 0.052 & $*$ & 0.030 \\
\hline Educational attainment & 0.013 & & 0.011 & 0.006 & & 0.011 \\
\hline Full-time work experience & 0.040 & $* * *$ & 0.007 & 0.036 & $* * *$ & 0.007 \\
\hline Part-time work experience & 0.014 & & 0.012 & 0.021 & $*$ & 0.012 \\
\hline Employment level (part-time) & 0.010 & & 0.062 & 0.001 & & 0.062 \\
\hline Employment level (not working) & -0.013 & & 0.144 & -0.021 & & 0.146 \\
\hline Job change (not applicable) & 1.025 & $* * *$ & 0.136 & 1.031 & $* * *$ & 0.138 \\
\hline Job change (no job change) & 0.915 & $* * *$ & 0.137 & 0.905 & $* * *$ & 0.139 \\
\hline Satisfaction with health & 0.337 & $* * *$ & 0.013 & 0.334 & $* * *$ & 0.013 \\
\hline Region & 0.371 & $* * *$ & 0.071 & 0.390 & $* * *$ & 0.071 \\
\hline Intercept & 4.242 & $* * *$ & 0.269 & & & \\
\hline Intercept (Base level: Mixed) & & & & 4.483 & $* * *$ & 0.274 \\
\hline Intercept (Base level: Intermittent) & & & & 4.281 & $* * *$ & 0.279 \\
\hline Intercept (Base level: Necessity) & & & & 4.152 & $* * *$ & 0.287 \\
\hline Intercept (Base level: Persistent) & & & & 4.678 & $* * *$ & 0.300 \\
\hline Intermittent (Base level: Mixed) & & & & -0.202 & $* * *$ & 0.077 \\
\hline Necessity (Base level: Mixed) & & & & -0.331 & $* * *$ & 0.092 \\
\hline Persistent (Base level: Mixed) & & & & 0.195 & $* *$ & 0.088 \\
\hline Mixed (Base level: Intermittent) & & & & 0.202 & $* * *$ & 0.077 \\
\hline Necessity (Base level: Intermittent) & & & & -0.130 & & 0.094 \\
\hline Persistent (Base level: Intermittent) & & & & 0.396 & $* * *$ & 0.096 \\
\hline Mixed (Base level: Necessity) & & & & 0.331 & $* * *$ & 0.092 \\
\hline Intermittent (Base level: Necessity) & & & & 0.130 & & 0.094 \\
\hline Persistent (Base level: Necessity) & & & & 0.526 & $* * *$ & 0.110 \\
\hline Mixed (Base level: Persistent) & & & & -0.195 & $* *$ & 0.088 \\
\hline Intermittent (Base level: Persistent) & & & & -0.396 & $* * *$ & 0.096 \\
\hline Necessity (Base level: Persistent) & & & & -0.526 & $* * *$ & 0.110 \\
\hline Observations & 4391 & & & 4391 & & \\
\hline Wald chi2 & 853.09 & $* * *$ & & 884.16 & $* * *$ & \\
\hline
\end{tabular}

$*, * *$, and $* * *$ denote significance at 10,5 , and $1 \%$ levels, respectively. 
TABLE 5

Results of Regression Analyses (DV: Life Satisfaction)

\begin{tabular}{|c|c|c|c|c|c|c|}
\hline \multirow[b]{3}{*}{ Gender } & \multicolumn{3}{|c|}{ Model 1} & \multicolumn{3}{|c|}{ Model 2} \\
\hline & \multicolumn{2}{|l|}{ Coef. } & \multirow{2}{*}{$\begin{array}{r}\text { S.E. } \\
0.057\end{array}$} & \multicolumn{2}{|l|}{ Coef. } & \multirow{2}{*}{$\frac{\text { S.E. }}{0.058}$} \\
\hline & 0.294 & $* * *$ & & 0.306 & $* * *$ & \\
\hline Age & -0.009 & $*$ & 0.005 & -0.012 & $* *$ & 0.005 \\
\hline Marital status & 0.227 & $* * *$ & 0.057 & 0.228 & $* * *$ & 0.057 \\
\hline Number of children & 0.033 & & 0.022 & 0.030 & & 0.022 \\
\hline Educational attainment & 0.030 & $* * *$ & 0.008 & 0.030 & $* * *$ & 0.008 \\
\hline Full-time work experience & 0.016 & $* * *$ & 0.005 & 0.018 & $* * *$ & 0.005 \\
\hline Part-time work experience & 0.004 & & 0.008 & 0.008 & & 0.009 \\
\hline Employment level (part-time) & -0.024 & & 0.046 & -0.026 & & 0.046 \\
\hline Employment level (not working) & -0.092 & & 0.075 & -0.099 & & 0.075 \\
\hline Job change (not applicable) & 0.076 & & 0.062 & 0.078 & & 0.062 \\
\hline Job change (no job change) & 0.202 & $* * *$ & 0.062 & 0.199 & $* * *$ & 0.062 \\
\hline Satisfaction with health & 0.309 & $* * *$ & 0.010 & 0.308 & $* * *$ & 0.010 \\
\hline Region & 0.470 & $* * *$ & 0.054 & 0.493 & $* * *$ & 0.054 \\
\hline Intercept & 3.853 & $* * *$ & 0.178 & & & \\
\hline Intercept (Base level: Mixed) & & & & 3.918 & $* * *$ & 0.180 \\
\hline Intercept (Base level: Intermittent) & & & & 3.854 & $* * *$ & 0.185 \\
\hline Intercept (Base level: Necessity) & & & & 3.961 & $* * *$ & 0.189 \\
\hline Intercept (Base level: Persistent) & & & & 4.098 & $* * *$ & 0.199 \\
\hline Intermittent (Base level: Mixed) & & & & -0.065 & & 0.059 \\
\hline Necessity (Base level: Mixed) & & & & 0.043 & & 0.067 \\
\hline Persistent (Base level: Mixed) & & & & 0.180 & $* *$ & 0.071 \\
\hline Mixed (Base level: Intermittent) & & & & 0.065 & & 0.059 \\
\hline Necessity (Base level: Intermittent) & & & & 0.108 & $*$ & 0.064 \\
\hline Persistent (Base level: Intermittent) & & & & 0.245 & $* * *$ & 0.073 \\
\hline Mixed (Base level: Necessity) & & & & -0.043 & & 0.067 \\
\hline Intermittent (Base level: Necessity) & & & & -0.108 & $*$ & 0.064 \\
\hline Persistent (Base level: Necessity) & & & & 0.137 & $*$ & 0.080 \\
\hline Mixed (Base level: Persistent) & & & & -0.180 & $* *$ & 0.071 \\
\hline Intermittent (Base level: Persistent) & & & & -0.245 & $* * *$ & 0.073 \\
\hline Necessity (Base level: Persistent) & & & & -0.137 & $*$ & 0.080 \\
\hline Observations & 5229 & & & 5229 & & \\
\hline Wald chi2 & 1265.52 & $* * *$ & & 1283.9 & $* * *$ & \\
\hline
\end{tabular}

$*, * *$, and $* * *$ denote significance at 10,5 , and $1 \%$ levels, respectively. 